\begin{abstract}
UNIVERSIDADE DE SÃO PAULO
FACULDADE DE MEDICINA DE RIBEIRÃO PRETO

PROGRAMA DE PÓS-GRADUAÇÃO EM PATOLOGIA EXPERIMENTAL
\end{abstract}

TAMARA SOLEDAD FRONTANILLA RECALDE

Distribuição da frequência alélica de STRs preconizados pelo sistema CODIS na capital e no Departamento Central do Paraguai.

Ribeirão Preto

2018 
Distribuição da frequência alélica de STRs preconizados pelo sistema CODIS na capital e no Departamento Central do Paraguai.

Versão Corrigida. A versão original encontra-se disponível tanto na biblioteca de unidade que aloja o Programa, quanto na Biblioteca Digital de Teses e Dissertações da USP (BDTD)

Dissertação apresentada ao Programa de Pós-Graduação em Patologia da Faculdade de Medicina de Ribeirão Preto da Universidade de São Paulo, para obtenção do Título de Mestre.

Orientador: Prof. Dr. Ricardo Henrique Alves da Silva.

Ribeirão Preto 


\section{Ficha catalográfica}

Elaborada pela Biblioteca Central do Campus USP - Ribeirão Preto

Recalde, Tamara Soledad Frontanilla.

Distribuição da frequência alélica de STRs preconizados pelo sistema CODIS na capital e no Departamento Central do Paraguai. Ribeirão Preto, 2018.

$96 \mathrm{p}$ : il ; $30 \mathrm{~cm}$.

Dissertação de Mestrado apresentada à Faculdade de Medicina de Ribeirão Preto/USP, Área de concentração Patologia

Orientador: Silva, Ricardo Henrique Alves

1. Identificação humana. 2. DNA. 3.Repetições de microssatélites.

4. Paraguay. 
RECALDE Tamara Soledad Frontanilla. Distribuição da frequência alélica de STRs preconizados pelo sistema CODIS na capital e no Departamento Central do Paraguai. 2018. 64f. Dissertação (Mestrado em Patologia Experimental) - Faculdade de Medicina de Ribeirão Preto, Universidade de São Paulo, Ribeirão Preto, 2018.

Aprovado em: 10 de dezembro de 2018

\section{Banca examinadora}

Prof. Dr. Ricardo Henrique Alves da Silva

Instituição: Faculdade de Odontologia de Ribeirão Preto - USP

Julgamento: Aprovado

Prof. Dr. Edgard Michel Crosato

Instituição: Faculdade de Odontologia, Universidade de São Paulo

Julgamento: Aprovado

Prof. Dr. Hermes de Freitas Barbosa

Instituição: Faculdade de Medicina de Ribeirão Preto - USP

Julgamento: Aprovado

Profa. Dra. Edna Sadayo Miazato Iwamura

Instituição: Universidade Federal de São Paulo

Julgamento: Aprovado 


\section{DEDICATÓRIA}

Aos meus pais, com amor, admiração e gratidão por tanto apoio, compreensão e amor incondicional em tantos anos de estudo. 


\section{AGRADECIMENTOS}

A Deus, por ter me dado a possibilidade de seguir meus sonhos, e a capacidade para descobri-los.

À minha família, pelo apoio incondicional. Especialmente aos meus pais, Mirian e Narciso, por me apoiarem, sem dúvidas, em todos os meus sonhos e projetos. Também, um carinho especial aos meus tios, Maria Lucia e Álvaro por terem me dado uma casa no Brasil, muito carinho e apoio sempre.

Ao meu professor e orientador Prof. Dr. Ricardo Henrique Alves da Silva, pela confiança, paciência, oportunidades profissionais, motivação e por contribuir de maneira inigualável na minha formação profissional.

Aos meus colegas e amigos do Departamento, por tantas risadas, tanto apoio e por fazerem as tardes de trabalho muito mais divertidas. Julia, Ana, Bruna, Paulo, Silmara, Coltri e, principalmente, Victor, Paula, Luciana e Beatriz, de coração muito obrigada por tanto.

Aos meus colegas e amigos do Paraguai, Natalia, Veronica, Jessica, Veronica, Mariela, Adriana, Guillermo, Dionny e Nancy pela ajuda na coleta das amostras e Gisselle, Andrea, Camila, Luciana e Alexia por tanto apoio em todos meus projetos e por serem pilares fundamentais na minha vida.

Ao meu namorado Jesus Ayala, pela ajuda nas análises estatísticas e por me alentar sempre a alcançar meus sonhos.

Ao Prof. Dr. Celso Teixeira Mendes Junior da Faculdade de Filosofia, Ciências e Letras de Ribeirão Preto por toda a ajuda e paciência.

À toda equipe do Laboratório de Genética da USP - Faculdade de Odontologia de Bauru, em especial à Profa. Dra . Elza Araújo Torres, ao Prof. Dr. Carlos Ferreira dos Santos e ao técnico do laboratório de Farmacologia da Universidade de Bauru Thiago José Dionísio.

A equipe da ThermoFisher Scientific, muito especialmente ao Sr. Weslley Tsumida pela ajuda, paciência e por me oferecer suporte e ajuda na realização dos testes. Sem dúvida foi indispensável no desenvolvimento da pesquisa.

Ao advogado Pastor Roche, por confiar em mim e pela ajuda incansável na busca do apoio financeiro.

Ao estatístico Antonin Charmeux pela paciência, ajuda e excelente predisposição.

Com todos e cada um de vocês, eternamente agradecida. 
"Do not give up because you are what this world needs. Because your capacity for sacrifice will give you a better future and to all, a better society. Don't give up. You're going to get it, because even if you do not believe it, you're already getting it." Julita Erre 


\section{RESUMO}

RECALDE Tamara Soledad Frontanilla. Distribuição da frequência alélica de STRs preconizados pelo sistema CODIS na capital e no Departamento Central do Paraguai. 2018. 64f. Dissertação (Mestrado em Patologia Experimental) - Faculdade de Medicina de Ribeirão Preto, Universidade de São Paulo.

Os marcadores utilizados para a obtenção de perfis genéticos são loci de regiões microssatélite do DNA, também designados de Short Tandem Repeats (STR). O número de repetições dos marcadores STR é variável entre os indivíduos, criando polimorfismo e tornando-os, desta forma, ótimos marcadores para identificação humana. $O$ objetivo desse trabalho foi estabelecer a distribuição da frequência alélica de 16 STRs preconizados no sistema CODIS, na capital e no Departamento Central de Paraguai. Foram estudadas 300 amostras de saliva coletadas com NUCLEIC-CARD ${ }^{\text {TM }}$ Collection Device System, de indivíduos paraguaios dentre 20 e 70 anos de idade, morando em uma das 20 cidades estudadas. Para o processamento foi utilizado o kit AmpFLSTR Identifiler Direct PCR Amplification ${ }^{\circledR}$ seguindo as fases de amplificação, genotipagem, e eletroforese capilar. Foi possível estabelecer o perfil genético de 259 amostras bem como os parâmetros forenses e, assim, calcular os loci mais polimórficos os quais foram FGA e D18S51 utilizando os softwares GenAIEx 6.5, Arlequin 3.5 e $\mathrm{R}$ 2.5. A distribuição das frequências alélicas de cada loci analisado permitiu estabelecer a caracterização genética da população estudada. Foi possível confirmar que a população do Paraguai se encontra em equilíbrio Hardy-Weinberg, com uma diversidade genética intrapopulacional de 0.794915 +/- 0.398307 e interpopulacional determinada pelo índice de fixação (FST) de 0.01112. A partir desse estudo, foi possível determinar as frequências alélicas de 15 STRs utilizados no sistema CODIS na capital e no Departamento Central do Paraguai bem como a caracterização genética e os parâmetros forenses da população estudada. Todos os loci estudados foram considerados muito informativos e úteis para a solução de problemas relacionados com identificação humana na amostra analisada.

Palavras-chave: Identificação humana. DNA. Repetições de microssatélites. Paraguay. 


\begin{abstract}
RECALDE T.S.F. Distribution of the allelic frequency of STRs recommended by the CODIS system in the capital and in the Central Department of Paraguay. 2018. 64f. Dissertação (Mestrado em Patologia Experimental) Faculdade de Medicina de Ribeirão Preto, Universidade de São Paulo, Ribeirão Preto, 2018.
\end{abstract}

The markers used to obtain genetic profiles are loci of DNA microsatellite regions, also called Short Tandem Repeats (STR). The number of repetitions of STR markers is variable between individuals, creating polymorphism and thus making them excellent markers for human identification. The objective of this work was to establish the distribution of the allelic frequency of 16 STRs recommended in the CODIS system, in the capital and in the Central Department of Paraguay. We studied 300 saliva samples collected from NUCLEIC-CARD TM Collection Device System of Paraguayan individuals between 20 and 70 years of age living in one of the 20 cities studied. For the processing, the AmpFLSTR Identifiler Direct PCR Amplification $®$ kit was used following the phases of amplification, genotyping, and capillary electrophoresis. It was possible to establish the genetic profile of 259 samples as well as the forensic parameters and thus to calculate the most polymorphic loci which were FGA and D18S51 using the software GenAIEx 6.5, Arlequin 3.5 and $R$ 2.5. The distribution of the allelic frequencies of each loci analyzed allowed to establish the genetic characterization of the studied population. It was possible to confirm that the population of Paraguay is in HardyWeinberg equilibrium, with an intrapopulation genetic diversity of $0.794915+/-$ 0.398307 and interpopulation by determination of the FUS of 0.01112 . From this study, it was possible to determine the allelic frequencies of 15 STRs used in the CODIS system in the capital and in the Central Department of Paraguay as well as the genetic characterization and forensic parameters of the studied population. All the loci studied were considered very informative and useful for the solution of problems related to human identification in the analyzed sample.

Keywords: Human identification. DNA. Microsatellite Repeats. 


\section{Lista de llustrações}

Figura 1- Posição de marcadores STR nos cromossomos humanos......... 25

Figura 2- $\quad$ Mapa do departamento central e da Capital do Paraguai............ 29

Figura 3- NUCLEIC-CARD ${ }^{\mathrm{TM}}$ Collection Device Thermo Fisher Scientific ${ }^{\mathrm{TM}}$, São Paulo, Brasil após da coleta das amostras. 30

Figura 4- Composição do AmpFISTR® Identifiler® Direct PCR Amplification Kit.

Figura 5- Eletroferograma ideal ilustrando os 16 STR dos 16 diferentes loci analisados (15 STR e AMEL). A coloração verde indicando a qualidade ideal do experimento.

Figura 6- Eletroferograma aceitável ilustrando os 16 STR dos 16 diferentes loci analisados (15 STR e AMEL). A coloração amarela recomendando uma avaliação cuidadosa. 34

Figura 7- Eletroferograma não aceitável. A coloração vermelha indicando a necessidade de refazer o processamento da amostra.

Figura 8- Frequência alélica do Locus D8S1179 exportada do software GenAIEx 6.5 na amostra estudada.

Figura 9- Frequência alélica do Locus D21S11 gerada pelo software GenAIEx 6.5 na amostra estudada.

Figura 10- Frequência alélica do Locus D7S820 gerada pelo software GenAIEx 6.5 na amostra estudada.

Figura 11- Frequência alélica do Locus CSF1PO gerada pelo software GenAIEx 6.5 na amostra estudada.

Figura 12- Frequência alélica do Locus D3S1358 gerada pelo software GenAIEx 6.5 na amostra estudada.

Figura 13- Frequência alélica do Locus TH01 gerada pelo software GenAIEx 6.5 na amostra estudada. 39

Figura 14- Frequência alélica do Locus D13S317 gerada pelo software GenAIEx 6.5 na amostra estudada.

Figura 15- Frequência alélica do Locus D16S539 gerada pelo software GenAIEx 6.5 na amostra estudada. 39

Figura 16- Frequência alélica do Locus D2S1338 gerada pelo software GenAIEx 6.5 na amostra estudada. 
Figura 17- Frequência alélica do Locus D19S433 gerada pelo software GenAIEx 6.5 na amostra estudada.............................................40

Figura 18- Frequência alélica do Locus vWA gerada pelo software GenAIEx 6.5 na amostra estudada.

Figura 19- Frequência alélica do Locus TPOX gerada pelo software GenAIEx 6.5 na amostra estudada.

Figura 20- Frequência alélica do Locus D18S51 gerada pelo software GenAIEx 6.5 na amostra estudada.

Figura 21- Frequência alélica do Locus D5S818 gerada pelo software GenAIEx 6.5 na amostra estudada.

Figura 22- Frequência alélica do Locus FGA gerada pelo software GenAlEx 6.5 na amostra estudada.

Figura 23- Probabilidade de exclusão para os 15 loci analisados. .45

Figura 24- Porcentagem de variância molecular. 47

Figura 25- Valores de FST para as populações comparadas. 47

Figura 26- Gráfico da Matriz de FST para as populações comparadas .47 


\section{Lista de tabelas}

Tabela1- Representação da distribuição amostral da população estudada 29

Tabela 2- $\quad$ Alelos presentes nos marcadores estudados das amostras 1-5..35

Tabela 3- $\quad$ Faixa de variação de alelos, números de alelos (N.A), os de maior e menor frequência em cada loci estudado excluindo o marcador de género AMEL.

Tabela 4- Distribuição das frequências alélicas dos 259 indivíduos paraguaios incluindo dos parâmetros forenses.

Tabela 5- Resultados do teste exato para o calculo do equilíbrio de HardyWeinberg. Valores de $p>0,05$ apresentam-se não significantes (ns) e $<0,05$ significantes.

Tabela 6- Resultados globais do teste AMOVA..................................46

Tabela 7- Resultados da estatística F............................................48 


\section{Lista de Abreviaturas e Siglas}

AFLP

AMEL

AMOVA

CEP

CONEP

CODIS

DGEEC

DNA

EDNAP

FIS

FIT

FST

FBI

HCRP

HE

$\mathrm{HO}$

INTERPOL ISFG

$\mathrm{mL}$

MP

NIST

LD

PCR

$\mathrm{PE}$

PD

$\mathrm{PI}$

PIC

RAPD

RFLP

SNP

STR

$\mu \mathrm{L}$

USP

VNTR

${ }^{\circ} \mathrm{C}$
Polimorfismo do Comprimento do Fragmento Amplificado

Amelogenina

Análise de Variância Molecular

Comitê de Ética e Pesquisa

Comissão Nacional de Ética em Pesquisa

Combined DNA Index System

Direção Geral de Estatísticas Pesquisas e Censos

Ácido Desoxirribonucleico

Grupo Europeu de Perfis de DNA

Coeficiente de Consanguinidade

Coeficiente de Consanguinidade Total

Indice de Fixação Total

Federal Bureau of Investigation

Hospital das Clínicas de Ribeirão Preto

Heterozigosidade Esperada

Heterozigosidade Observada

Organização Internacional de Polícia Criminal

Sociedade Internacional de Genética Forense

Mililitro

Probabilidade de coincidência (matching)

National Institute of Standards and Technology

Desequilíbrio de Ligação

Reação em Cadeia da Polimerase

Poder ou Probabilidade de Exclusão

Poder ou Probabilidade de Discriminação

Poder de Inclusão

Conteúdo de Informação Polimórfica

DNA Polimórfico Amplificado Aleatoriamente

Fragmentos de Restrição Polimórfica

Polimorfismo de Nucleotídeo Único

Sequências Curtas Repetidas em Tandem

Microlitro

Universidade de São Paulo

Número Variável de Repetições em Tandem

Grau Celsius 


\section{Sumário}

1. INTRODUÇÃO

$1.1 \quad$ Estrutura do DNA e marcadores moleculares............................................ 16

1.2 Identificação humana e aplicação da Genética Forense ............................ 18

1.3 Polimorfismos genéticos e a identificação humana .................................... 19

1.4 Parâmetros estatísticos em Genética Forense ............................................... 21

1.5 Perfil de DNA e identidade genético-criminal .............................................. 23

1.6 Banco de dados genético e direitos humanos............................................25

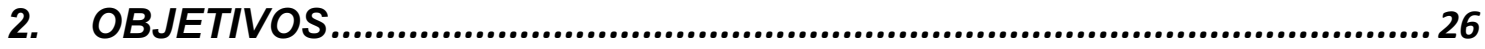



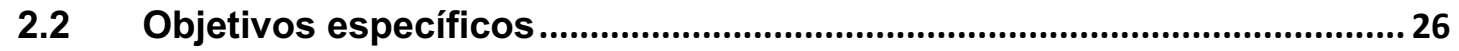



4. MATERIAIS E MÉTODOS ................................................................. 27

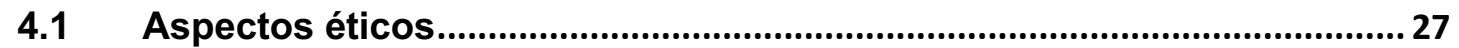

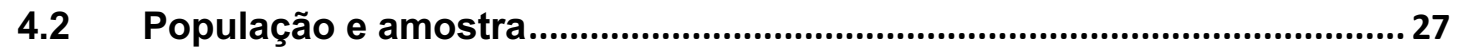

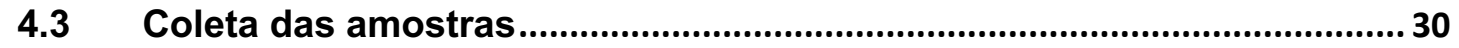

$4.4 \quad$ Transporte e armazenamento das amostras ............................................ 30

4.5 Processamento das amostras ........................................................................... 30

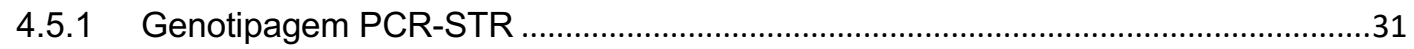

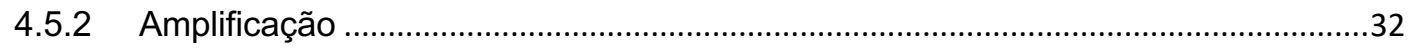

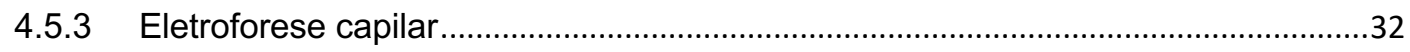

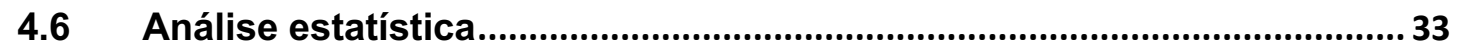

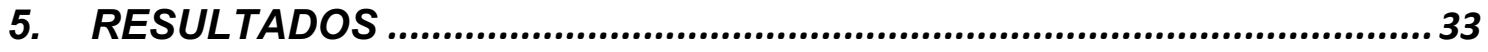

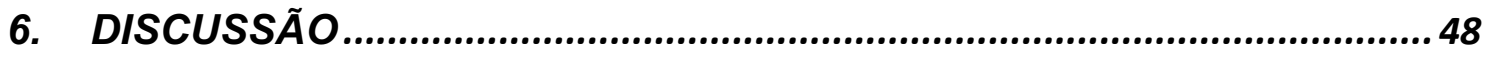

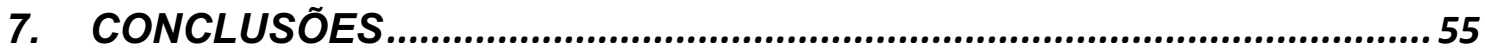

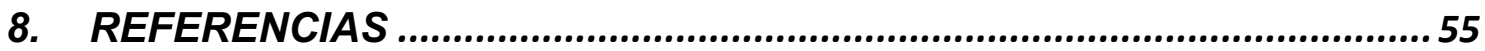

9. ANEXO 


\section{INTRODUÇÃO}

\subsection{Estrutura do DNA e marcadores moleculares}

O ácido desoxirribonucleico (DNA) é um ácido nucleico, formado por uma dupla fita em hélice, constituída por bases nitrogenadas organizadas em cadeias polinucleotídicas (GRIFFITHS, et al., 2013). Os ácidos nucleicos, incluindo o DNA, são compostos por unidades de nucleotídeos; constituídas por uma base nucleica, um açúcar e um fosfato. As bases nucleicas que formam o nosso DNA, são: A (adenina), T (timina), C (citosina) e G (guanina), e as suas várias combinações, produzem as diversas diferenças biológicas entre os seres humanos e todas as criaturas vivas (BUTLER, 2010).

O DNA é referido como a nossa impressão genética, porque armazena as informações necessárias para passar os atributos genéticos para futuras gerações. O conjunto completo do DNA contido em uma célula é referido coletivamente como seu genoma (BUTLER, 2010; KRISHNAMURTHY; MANOJ; PAGARE, 2011).

Os seres humanos têm aproximadamente 3 bilhões de posições de nucleotídeos em seu DNA genômico. Assim, com quatro possibilidades (A, T, C ou G) em cada posição, são possíveis inúmeras combinações, sempre levando em consideração que a adenina só pode se hibridar com a timina e a citosina com a guanina (BUTLER, 2010). O conteúdo informativo do DNA é codificado na ordem (sequência) das bases e a informação no DNA é armazenada com base na ordem dos nucleotídeos, genes e cromossomos (HOOD; GALAS, 2003).

O material de DNA nos cromossomos é composto de regiões "codificadoras" e "não codificadoras". As primeiras, são conhecidas como genes, e contêm as informações necessárias para uma célula produzir proteínas, constituindo apenas 5\% do nosso DNA genômico (HOOD; GALAS, 2003; BUTLER; COBLE; VALLONE, 2017). As regiões de DNA que não codificam proteínas compõem o restante do nosso material cromossômico, e nelas podem ser encontradas marcadores moleculares altamente polimórficos (variáveis) que diferem entre os indivíduos (BUTLER, 2010).

Os marcadores moleculares correspondem, basicamente, a uma sequência de nucleotídeos que atua como referência em um cromossomo. Em outras palavras, são segmentos de DNA com uma localização física identificável (locus) 
em um cromossomo e cuja herança genética pode ser rastreada. Um marcador pode ser um gene, ou uma seção do DNA sem função conhecida. Vários tipos de marcadores moleculares foram identificados ao longo do tempo. Eles podem ser baseados em Fragmentos de Restrição Polimórfica (RFLP) e na Reação em Cadeia da Polimerase (PCR) (HOOD; GALAS, 2003; BUTLER, COBLE; VALLONE, 2017; BUTLER, 2010).

Marcadores polimórficos são os que apresentam variação em sua sequência entre indivíduos e são usados para construir mapas de ligação gênica. Este polimorfismo pode residir no número de repetições, no tamanho da unidade de repetição ou ainda na composição da unidade de repetição, sendo que esta última é dividida em repetições simples, compostas, complexas e complexas hipervariáveis (MATOS, 2013).

O tipo de variação determina qual o tipo de polimorfismo, que pode ser um RFLP (polimorfismo do tamanho da sequência de restrição), VNTR (número variável de repetições em tandem; cada alelo do locus possui um número diferente de cópias de um motivo em comum), SNP (polimorfismo de nucleotídeo único; consiste na variação de um único nucleotídeo) ou STR (sequências curtas repetidas em tandem) (BECERRA; PAREDES, 2000; MATOS, 2013).

As sequências tipo microssatélite (SSR ou STR), estão constituídas por unidades curtas de um a seis pares de bases que se repetem (GRIFFITHS, et al., 2013). Sua frequência e tipo de repetição variam nos genomas de diferentes espécies. Por meio dos microssatélites, a diversidade entre genótipos pode ser medida por PCR amplificando a região do DNA genômico contendo essas sequências repetidas (BECERRA; PAREDES, 2000).

Os microssatélites apresentam vantagens como a codominância, multialelismo e alta heterozigosidade. (BECERRA; PAREDES, 2000). O alto nível de polimorfismo, permite uma discriminação precisa entre indivíduos altamente relacionados. (CAVALCANTE; QUEIROZ, 2013; GRIFFITHS, et al., 2013). Além de serem altamente polimórficos, mostrando-se inclusive mais variáveis que os RFLP, AFLP e RAPD, os microssatélites requerem quantidades mínimas de DNA, o que constitui uma vantagem favorável (PERL-TREVES et al.,1985).

De acordo com as recomendações da Sociedade Internacional de Genética Forense (ISFG), a designação dos alelos dos STR deve fazer-se de acordo com 
o número de unidades de repetição (OLIVEIRA,2012). Existem situações onde um alelo de um locus STR contém um número incompleto de repetições, dando origem desta forma às microvariantes. Este termo descreve os alelos que contem unidades de repetição incompleta. Portanto, se um alelo apresentar uma unidade de repetição incompleta, será designado pelo número de unidades de repetição completas e pelo número de pares de bases da unidade de repetição incompleta, separados por um ponto (DIXON et al., 2006).

As microvariantes de cada marcador molecular, descritas na literatura atualmente, podem ser consultadas na base de dados da NIST (National Institute of Standards and Technology). Desta forma, se pesquisas recentes encontrarem novas microvariantes ainda não descritas, poderão contribuir com a tabela.

\subsection{Identificação humana e aplicação da Genética Forense}

Um dos maiores desafios na área forense é a identificação humana. A identidade pode ser compreendida como conjunto de características que distinguem uma pessoa ou uma coisa, e por meio das quais é possível individualizá-la (HOUAISS; VILLAR; FRANCO, 2001).

A possibilidade de individualização humana por características particulares possibilita a identificação em situações sumamente importantes, quais sejam: situações catastróficas (acidentes aéreos, desastres naturais, guerras), homicídios com segmentação de partes corporais das vítimas, imersão, carbonização, etc. (JOBIM; COSTA; SILVA, 2012).

A INTERPOL (INTERPOL, 2014) estabelece métodos de identificação primários e secundários. Os primários podem ser entendidos como aqueles que podem por si só estabelecer a identidade, ou seja, sem necessidade de aplicar outro método para confirmação. Estes métodos são a datiloscopia, a odontologia e a genética. Já os métodos secundários de identificação, têm como principal objetivo diminuir o universo de busca, portanto constituem métodos auxiliares. Eles por si só, não podem estabelecer a identidade. Entre eles, encontram-se a antropologia, tatuagens, vestimentas, entre outros.

O DNA tem sido o responsável por uma verdadeira revolução das técnicas de identificação nas últimas décadas (CAVALCANTE; QUEIROZ, 2013), a partir do estudo e da identificação de polimorfismos entre determinados marcadores moleculares existentes nos indivíduos. Estes marcadores têm grande potencial 
discriminatório (SZIBOR et al., 2003) podendo, assim, serem utilizados em investigações criminais.

A maior parte da sequência de bases nitrogenadas do DNA dos seres humanos apresenta baixa discriminação, inclusive o projeto genoma humano, revelou que a sequência do genoma humano é 99,9\% exatamente a mesma em todas as pessoas (BUTLER, 2010). Entretanto, existem regiões polimórficas cuja sequência de bases varia entre os indivíduos. A análise dessas regiões permite a elaboração de perfis genéticos com o potencial de traduzir informações contidas no DNA na forma de algarismos alfanuméricos que se repetem (LIMA,2008; GRIFFITHS, et al., 2013).

A identificação humana utilizando o método genético é realizada por meio do estudo de marcadores genéticos. De acordo com o Grupo Europeu de Perfis de DNA (EDNAP), os marcadores recomendados para a obtenção de perfis genéticos são loci de regiões microssatélite do DNA, também designados de short tandem repeats (STR) (PINHEIRO, 2010; PINHEIRO,2015).

A estabilidade química do DNA, mesmo após longo período de tempo, e a sua ocorrência em todas as células nucleadas do organismo humano atribuem a este método uma ampla vantagem e efetividade (LEITE et. al., 2013). Entretanto, como todo método, tem limitações consideráveis devido ao custo, tempo de processamento e necessidade de estudos genéticos populacionais que permitam conhecer melhor as características genéticas das diferentes populações para assim conseguir melhores resultados.

\subsection{Polimorfismos genéticos e a identificação humana}

O termo polimorfismo refere-se à ocorrência simultânea de diferentes genótipos, resultantes da combinação de alelos de um mesmo locus dentro da população, que podem ou não resultar em diferentes fenótipos. (UTIYAMA; REASON; KOTZE, 2004). Em outras palavras, uma variação genética descontínua que resulta em diferentes formas ou tipos de indivíduos entre os membros de uma única espécie (SNUSTAD; SIMMONS, 2001).

O polimorfismo genético promove a diversidade dentro de uma população. Muitas vezes, persiste por muitas gerações, porque nenhuma forma única tem uma vantagem ou desvantagem geral sobre as outras em relação à seleção 
natural. Um exemplo comum são as diferentes formas alélicas que dão origem a diferentes tipos sanguíneos em humanos. (DIAS, et. al, 2017)

Atualmente, aceita-se que um gene com frequência entre 1\% e $99 \%$ deve ser classificado como gene polimorfo, aquele inferior a $1 \%$ idiomorfo, enquanto um gene com frequência superior a $99 \%$ deve ser classificado como gene monomorfo (MORTON, 1976). Entretanto, é importante deixar claro que um locus polimórfico pode incluir entre os alelos a ele pertencentes um ou vários genes idiomorfos. Por sua vez, os caracteres que resultam de loci que incluem pelo menos dois alelos polimórficos são denominados polimorfismos genéticos ou sistemas genéticos polimórficos. (BEIGUELMAN B, 2008; UTIYAMA; REASON; KOTZE, 2004)

O número de repetições dos marcadores STR é variável entre os indivíduos, criando polimorfismo e tornando-os, desta forma, ótimos marcadores para identificação humana, mas também definindo formas variantes dos alelos presentes na população (MARTINS, 2008). Desta forma, uma estratégia para compreender melhor a constituição genética de uma população é estimar a distribuição das frequências alélicas de regiões microssatélites (GIGONZAC, 2013).

A variação genética dentro da população é responsável pela maioria da diversidade humana (LI et al, 2009). A Genética Populacional tem como um dos objetivos analisar as consequências da aplicação dos princípios mendelianos em determinada população, estudando os efeitos das mutações (OLIVEIRA, 2012). E na identificação humana isto é sumamente importante, pois em uma valoração pericial é necessário conhecer alguns parâmetros estatísticos da população referência (BEIGUELMAN, 2008).

Cada população tem um grau de diferenciação distinta. Sabe-se que diferentes populações apresentam alelos em frequências diferentes e algumas vezes únicos (EHRLICH; RAVEN, 1969) e, mesmo em países vizinhos ou de costumes similares, existe polimorfismo. Portanto, é de suma importância a realização de estudos populacionais e de caracterização genética, a fim de verificar quais alelos estão presentes e em qual frequência, para definir quais são os melhores marcadores a serem utilizados nestes casos, provando a efetividade de métodos internacionais na população estudada. 
Como todo método de identificação, o método de DNA é baseado no confronto de dados, sendo necessário ter material biológico do suspeito que permita a comparação de dados (INTERPOL, 2014). É claro que em casos onde busca-se a vinculação de um acusado vivo ao local de crime constitui um processo muito mais simples devido a que a amostra é obtida diretamente do suspeito, sem contaminação, degradação ou dúvida da procedência da amostra.

Paralelamente, em casos onde busca-se a identificação de um cadáver em avançado estado de decomposição, o DNA já se encontra degradado, o que dificulta o processamento. Além disso, para o confronto de dados buscam-se objetos pessoais ou familiares da vítima para obter material biológico que permita fazer o confronto, o que pode abrir uma grande discussão a respeito da validade da amostra indubitada. Uma solução a esta problemática poderia ser a criação de um banco de dados genético que permita o armazenamento de perfis genéticos da população e sua utilização direta logo em casos de investigação. (BUDOWLE; BIEBER; EISENBERG, 2005)

\subsection{Parâmetros estatísticos em Genética Forense}

A base para os cálculos de frequência alélica, derivam do Princípio de HardyWeinberg que constitui em um modelo matemático simples para demonstrar que as frequências genotípicas de uma população se mantêm constantes quando não há força evolutiva atuando sobre a mesma, ou seja, a herança mendeliana, por si só, não gera mudança evolutiva.

Para que o princípio possa ser demonstrado, a população em questão deve estar em equilíbrio genético, devendo ela apresentar as seguintes características (BEIGUELMAN, 2008): (a) A população analisada deve ser grande o suficiente para que não ocorram desvios estatísticos; (b) Não deve haver fluxo gênico entre diferentes populações; (c) Não deve haver a ocorrência de mutações; (d) Os casamentos devem ocorrer aleatoriamente, não existindo, por conseguinte, casamentos preferenciais entre indivíduos por causa de seu genótipo, fenótipo, estratificação social ou consanguinidade. Aliás, por serem os casamentos realizados aleatoriamente, os casamentos consanguíneos podem existir, desde que ocorram aleatoriamente; (e) Não pode haver atuação da seleção natural.

Este tipo de população é chamada de população ideal e apesar de nenhuma população humana preencher as condições descritas acima, a prática tem 
demonstrado que em numerosas populações humanas, os genótipos se distribuem de acordo com a Lei de Hardy-Weinberg, sendo esta muito útil para se estudarem populações e os mecanismos evolutivos que violam o Principio (BEIGUELMAN, 2008; OLIVEIRA 2012).

Para que um marcador possa ser utilizado, deve cumprir com alguns parâmetros forenses e, entre eles, encontramos:

a) Poder de Exclusão: O PE de um marcador genético numa determinada população é um parâmetro importante no que concerne à investigação biológica da paternidade. Pode ser definido como a probabilidade de excluir um indivíduo que foi erroneamente acusado em uma investigação de paternidade (BEIGUELMAN, 2008).

b) Poder de Discriminação: O PD é a probabilidade de dois indivíduos, retirados ao acaso da mesma população e não aparentados entre si, se possam diferenciar geneticamente, ou seja, apresentarem genótipos diferentes (DESMARAIS et al., 1998). Quanto maior for o número de sistemas genéticos considerados, maior o valor de PD, existindo maior capacidade de discriminar vários indivíduos de uma população.

c) Probabilidade de identidade (PI) ou Probabilidade de Matching (MP): é a probabilidade de dois indivíduos escolhidos ao acaso em uma população apresentarem genótipos idênticos para um locus. Portanto, é o oposto da Probabilidade de Discriminação (SENSABAUGH, 1982).

d) Heterozigosidade: Trata-se de um parâmetro que representa a probabilidade de dois alelos do mesmo locus, escolhidos ao acaso na população, serem diferentes (WEIR, 1996). Quanto maior a heterozigose, maior é a variabilidade genética do locus na população em questão, assim, a probabilidade de que dois indivíduos tenham o mesmo perfil torna-se menor. O ideal é utilizar marcadores genéticos que tenham heterozigose superior a $70 \%$, pois são mais informativos. A heterozigose pode ser esperada ou observada. (SANTA RITA, 2013). A heterozigosidade observada $\left(\mathrm{H}_{\mathrm{O}}\right)$ define- se como o número de indivíduos heterozigóticos observados, relativamente ao número total de indivíduos da população. É calculada diretamente dos genótipos encontrados na população. Trata- se do número de heterozigotos em cada locus dividido pelo número total de indivíduos pesquisados. A heterozigosidade 
esperada $\left(\mathrm{H}_{\mathrm{e}}\right)$ é a fração estimada de heterozigotos para um locus, assumindo a condição de equilíbrio de Hardy-Weinberg na população. Difere-se da observada por ser calculada a partir das frequências alélicas. Quando $\mathrm{H}_{\mathrm{o}}$ encontra-se maior que a $\mathrm{H}_{\mathrm{e}}$ significa que existe um excesso de heterozigotos em relação ao modelo de equilíbrio de Hardy-Weinberg. Entretanto, quando a $\mathrm{H}_{\mathrm{o}}$ se apresenta menor que a $\mathrm{H}_{\mathrm{e}}$ significa que existe um excesso de homozigotos em relação ao modelo de equilíbrio. Portanto, o ideal é que ambas apresentem valores similares.

e) Conteúdo Informativo de Polimorfismo (PIC): É a capacidade informativa de um locus analisando-se seu conteúdo em informação polimórfica (BOTSTEIN et al., 1980): PIC superiores a 0,5 são considerados muito informativos. Valores entre 0,25 e 0,5 são considerados razoavelmente informativos e valores menores que 0,25, pouco informativos (BOTSTEIN et al., 1980).

\subsection{Perfil de DNA e identidade genético-criminal}

As regiões polimórficas do DNA foram descritas na década de 1980, na Inglaterra, pelo cientista Alec Jeffreys que ao estudar um determinado gene, se surpreendeu observando que em sua extensão apareciam regiões que se diferenciavam entre as pessoas, e observou que estas regiões variáveis podiam ser encontradas em todo o genoma humano e que a partir delas podia-se definir o que ele mesmo chamou de "impressões digitais de DNA" (JEFFREYS; BROOKFIELD; SEMEONOFF, 1985; BERNATH, 2008).

As impressões digitais de DNA tornaram-se uma ferramenta muito útil nas investigações criminais. Perfis de DNA forense são atualmente realizados utilizando um painel de marcadores STR multialélicos estruturalmente análogos aos minissatélites originais, mas com curtos intervalos de repetição e, portanto, mais fáceis para amplificar e "multiplexar" com a reação em cadeia da polimerase. Até 30 STRs podem ser detectados em uma única eletroforese capilar, gerando para cada indivíduo um código único (ROEWER, 2013).

Existem dois conjuntos de marcadores STR que cumprem os requerimentos dos bancos de dados criminais em todo o mundo: o conjunto padrão europeu de 12 marcadores (JOBLING; GILL, 2004) e o padrão norte-americano CODIS 
(Combined DNA Index System) de atualmente 20 marcadores (COLLINS et al., 2004).

O CODIS é um programa criado em 1998, de propriedade exclusiva do Federal Bureau of Investigation (FBI), que permite a comparação de perfis genéticos. Combina a ciência forense e informática em uma ferramenta para a ligação de crimes violentos e permite que laboratórios forenses federais, estaduais e locais troquem e comparem perfis de DNA eletronicamente, ligando assim crimes violentos em série entre si e a ofensores conhecidos. Usando o Sistema Nacional de Indexação de DNA do CODIS, o Banco de Dados Nacional de DNA de Pessoas Desaparecidas também ajuda a identificar indivíduos desaparecidos e não identificados (Federal Bureau of Investigation, USA).

Nos Estados Unidos, o CODIS não é acessível ao público em geral ou para a maioria dos profissionais da justiça criminal. Apenas o administrador do banco de dados em laboratório do governo e o pessoal responsável pela entrada de perfis de DNA para CODIS têm acesso ao banco de dados de DNA em todos os níveis (local, estadual e nacional) (Federal Bureau of Investigation, USA).

Os Estados Unidos preconizaram, inicialmente, 13 loci designados como painel de STR do CODIS composto pelos loci autossômicos TPOX, D3S1358, FIBRA ou FGA, D5S818, CSF1PO, D7S820, D8S1179, TH01, vWA, D13S317, D16S539, D18S51, D21S11 e o gene homólogo da amelogenina (X e Y) (CAVALCANTE; QUEIROZ, 2013) (Figura 1). Em maio de 2010, o FBI formou um CODIS Core Loci Working Group1 para rever os 13 loci principais existentes e determinaram ser vantajoso ter loci adicionais, devido a que reduziria a probabilidade de correspondências ao acaso, aumentaria a compatibilidade internacional para auxiliar os esforços de compartilhamento de dados e acresceria o poder de discriminação para auxiliar casos de desaparecidos (HARES, 2015; KRAEMER et al., 2017). Portanto, foram acrescentados os loci D10S1248, D22S1045, D1S1656, D12S391, D2S441, D2S1338, D19S433, PentaD e PentaE (AGUIAR, 2014). 
Figura 1 - Posição de marcadores STR nos cromossomos humanos.

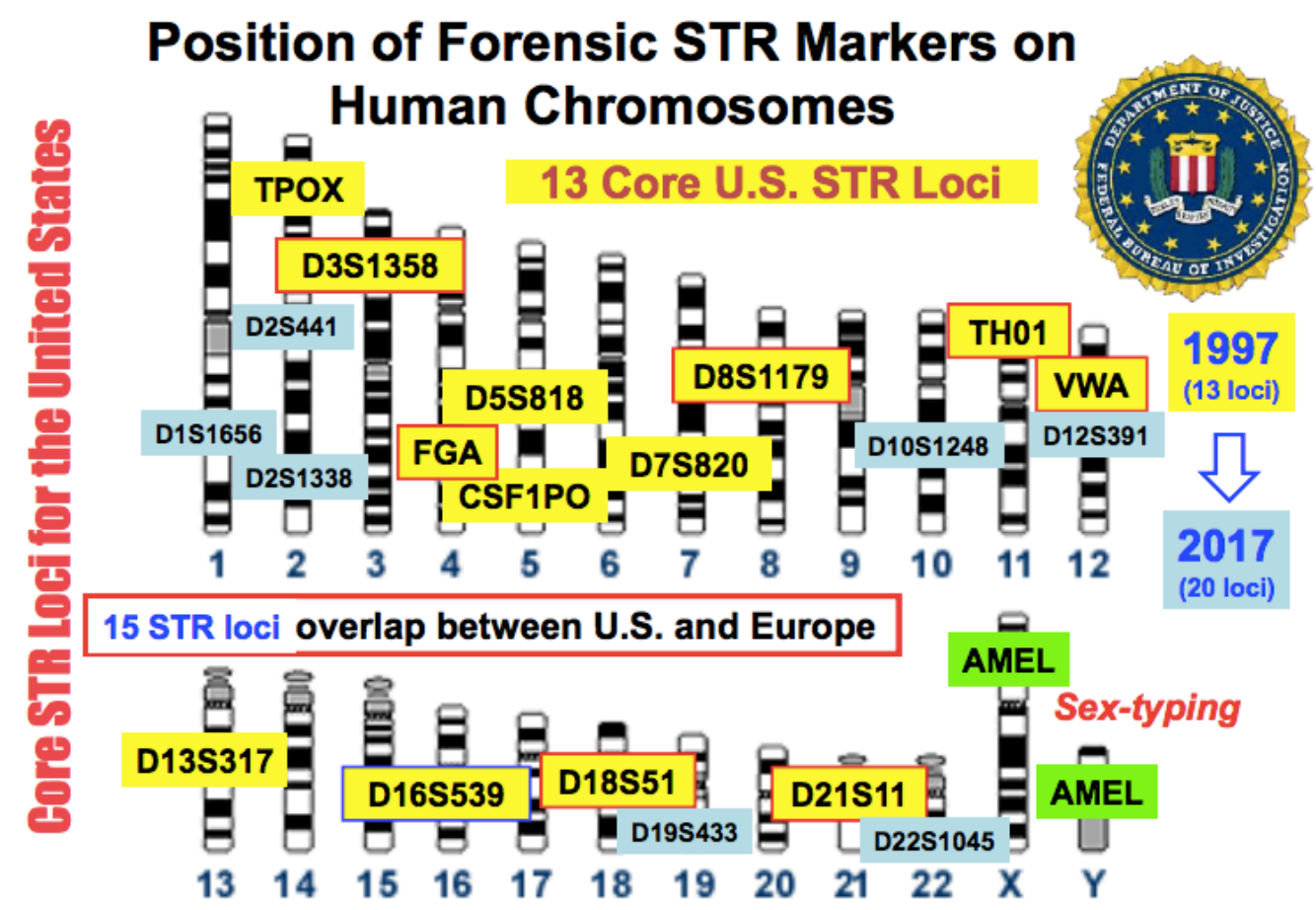

Fonte: BUTLER, 2015. Disponível em: http://www.cstl.nist.gov/strbase/pub_pres/Butler-DNAinterpretation-AAFS2015.pdf. Acessado em 3/06/2018).

\subsection{Banco de dados genético e direitos humanos.}

O primeiro banco de dados de DNA forense no mundo foi o banco de dados nacional do Reino Unido, estabelecido em 1995. Embora ele tenha sido inicialmente amplamente apoiado pelo público, a grande expansão do banco de dados, e a possibilidade que os perfis de DNA sejam mantidos no banco de dados mesmo após a absolvição, levou ao registro de um número significativo de pessoas inocentes, tornando-se assim, altamente controverso (NUFFIELDCOUNCIL, 2007; WALLACE et al., 2017). Posteriormente, a lei foi alterada, permitindo que mais de 1 milhão de perfis de DNA de pessoas inocentes fossem retiradas desse banco de dados genético-criminal (WILLIAMS; JOHNSON; MARTIN, 2004).

Uma base de dados genética com finalidades forenses agrega um conjunto de perfis genéticos que são determinados a partir de amostras biológicas colhidas de um conjunto de indivíduos ou encontradas em cenas de crime. Em contexto de investigação criminal, os perfis genéticos obtidos por essas vias poderão ser comparados com os perfis já incluídos em base de dados, com vistas a apurar se ocorre ou não uma correspondência positiva. $O$ arquivamento 
dos perfis genéticos e qualquer outro tipo de informação constante na base de dados, é realizado em ficheiros informatizados. A utilização de bases de dados genéticos forenses pode ser utilizada para diversos fins, tais como: para identificação de autores e de vítimas de crimes, vítimas de catástrofes, pessoas desaparecidas e para o estabelecimento dos laços de parentesco entre indivíduos (MACHADO; MONIZ, 2014).

Evidentemente, mesmo que esteja amplamente comprovado que a engenharia genética trouxe avanços inigualáveis no entendimento das enfermidades, novas terapias e cura de inumeráveis patologias, existe uma preocupação ética referente aos perfis genéticos de pessoas humanas. As aplicações atuais da engenharia genética demonstram um caráter ambivalente, de proteção e afronta concomitante a diversos princípios de direitos humanos, porquanto incluem certas situações de possível proteção e outras de ofensa à dignidade da pessoa humana (CAMARGO, 2013).

\section{OBJETIVOS}

\subsection{Objetivo geral}

O objetivo desse trabalho foi estabelecer a distribuição da frequência alélica de 16 STRs utilizados no sistema CODIS na capital e no Departamento Central do Paraguai.

\subsection{Objetivos específicos}

2.2.1 Determinar se a população da capital e do Departamento Central do Paraguai encontra-se no equilíbrio de Hardy-Weinberg.

2.2.2 Estabelecer a caracterização genética da capital e do Departamento Central do Paraguai.

2.2.3 Definir os marcadores genéticos mais importantes na prática forense na esfera criminal na população estudada.

2.2.4 Avaliar a possibilidade da realização de um banco de dados genético da população de referência. 


\section{JUSTIFICATIVA}

Não existem dados oficiais sobre a composição étnica da população paraguaia. A colonização Europeia, e as guerras pelas quais atravessou o país, foram fundamentais para composição genética atual. Conhecer a composição genética da população, bem como os parâmetros forenses de marcadores moleculares específicos é fundamental na resolução de investigações criminais.

\section{MATERIAIS E MÉTODOS}

O presente trabalho foi realizado com apoio da Coordenação de Aperfeiçoamento de Pessoal de Nível Superior - Brasil (CAPES) - Código de Financiamento 001.

\subsection{Aspectos éticos}

O projeto de pesquisa foi submetido e aprovado pelo Comitê de Ética em Pesquisa da Faculdade de Ciências Médicas da Universidade Nacional de Assunção (Paraguai), tendo em vista que os sujeitos da pesquisa são indivíduos paraguaios. E para fins de esclarecimentos frente aos questionamentos éticos, é de fundamental importância ressaltar que durante a coleta de material genético, apenas foram registrados em forma de código as seguintes informações: sexo, idade e cidade, não sendo arquivados nomes, números de documentos ou quaisquer outras informações que permitam identificar as pessoas, conforme determinam as normas constitucionais nacionais, do CEP (Comitê̂ de ética em Pesquisa) e da CONEP (Comissão Nacional de ética em Pesquisa), e internacionais sobre direitos humanos, genoma humano e dados genéticos (CONEP, 2002).

\subsection{População e amostra}

Foi feito um calculo amostral utilizando a amostra por quotas, a qual é constituída respeitando a distribuição populacional de cada cidade, levando em consideração a distribuição geográfica e dados estatísticos fornecidos pela Direção Geral de Estatísticas, Pesquisas e Censos do país. $\mathrm{O} n$ foi calculado utilizando o tamanho de amostra mínimo; $n=t^{2} \times p \times(1-p) / m^{2}$ onde ta representa o intervalo de confiança (95\%), $p$ a frequência do alelo 
(desconhecido, portanto utilizamos 0,5 para maximizar o n) e $m$ representa o margem de erro (utilizaremos $6 \%$ ). Desta forma, obtemos $n=1,96^{2} \times 0,5 \times 0,5 /$ $0,06^{2}=266,78$. Portanto, 260 pessoas constituem um numero representativo da população estudada.

Desta forma, a amostra consistiu em 300 adultos paraguaios voluntários residentes no Departamento Central do Paraguai, com idade entre 20 e 70 anos, divididos igualmente entre os sexos feminino e masculino, pois segundo dados estatísticos da Direção Geral de Estatísticas Pesquisas e Censos do Paraguai, (DGEEC), na capital $47,1 \%$ da população corresponde ao sexo masculino e o $52,9 \%$ ao sexo feminino (GOBIERNO NACIONAL, 2012) e no Departamento Central, $49,3 \%$ corresponde ao sexo masculino e o $50,7 \%$ ao sexo feminino, demonstrando a proporcionalidade existente na distribuição da amostra estudada, embora não tenha sido detectada nenhuma interferência do sexo na distribuição de STR por se tratarem de genes autossômicos (Tabela 1).

Foram considerados como objeto deste estudo, a capital e o Departamento Central pois apresentam a maior taxa de migração interna no país e, com isso, uma melhor representação da população Paraguai

A Organização Internacional para as Migrações (ORGANIZACIÓN INTERNACIONAL PARA LAS MIGRACIONES, sn.) expõe que mais de dois terços da população paraguaia se concentra na região metropolitana, composta de Assunção e seus arredores (Luque, Fernando de la Mora, San Lorenzo, Lambaré, Mariano Roque Alonso, Nemby, Capiatá, Limpio, San Antonio, Villa Elisa, Itauguá, e Ypacaraí, todos eles parte do Departamento Central de Paraguai) com uma população aproximada de 2.596.231 habitantes de acordo com dados da direção geral de estatísticas, pesquisas e censos. (GOBIERNO NACIONAL, 2012). 
Tabela 1 - Representação da distribuição amostral da população estudada. $(n=300)$

\begin{tabular}{lccc}
\hline CIDADE & $\begin{array}{c}\text { POPULAÇÃO } \\
\text { ESTIMADA }\end{array}$ & AREA Km ${ }^{2}$ & AMOSTRAS \\
\hline Areguá & 70.490 & 110 & 8 \\
Capiatá & 224.152 & 83 & 26 \\
Fernando de la Mora & 167.018 & 21 & 20 \\
Guarambaré & 33.208 & 59 & 4 \\
Itá & 75.606 & 190 & 9 \\
Itauguá & 100.456 & 122 & 12 \\
J.A.S & 51.891 & 95 & 6 \\
Lambaré & 170.851 & 39 & 20 \\
Limpio & 131.728 & 118 & 16 \\
Luque & 263.604 & 203 & 31 \\
MRA & 97.585 & 50 & 11 \\
Nemby & 131.048 & 40 & 15 \\
Nueva Italia & 11.934 & 312 & 1 \\
San Antonio & 62.663 & 29 & 7 \\
San Lorenzo & 252.561 & 41 & 30 \\
Villa Elisa & 75.933 & 22 & 9 \\
Villeta & 36.985 & 888 & 4 \\
Ypacaraí & 26.446 & 111 & 3 \\
Ypané & 48.772 & 54 & 6 \\
Asunción & 524.190 & 128 & 62 \\
\hline & & & \\
& & 59 & \\
\hline
\end{tabular}

Figura 2 - Mapa do departamento central e da Capital do Paraguai. Em vermelho o departamento central e em azul a Capital (A). Cidades que compõem o departamento central do Paraguai (B)






\subsection{Coleta das amostras}

Previamente à coleta das amostras, todos os participantes foram informados sobre a pesquisa, utilizando o termo de consentimento livre e esclarecido, sendo este documento devidamente preenchido, seguindo as normativas do Comitê de Ética e Pesquisa ao qual essa pesquisa foi submetida.

Os critérios de inclusão para seleção de voluntários foram: indivíduos paraguaios, com idade entre 20 e 70 anos, morando em uma das 20 cidades estudadas, seguindo a distribuição geográfica conforme exposto na Tabela 1. 0 critério de exclusão foi apresentar vínculo familiar ou consanguinidade entre voluntários. Foram coletadas amostras de saliva com o NUCLEIC-CARD ${ }^{\mathrm{TM}}$ Collection Device System dos diferentes postos de saúde das cidades estudadas, identificando sexo, idade e cidade de cada voluntario (Figura 3).

Figura 3 - NUCLEIC-CARD TM Collection Device após da coleta das amostras. Etiquetadas especificando idade, sexo e cidade (A). A região branca nos cartões de coleta, indicam a presença de saliva $(B)$



\subsection{Transporte e armazenamento das amostras}

As amostras coletadas com o NUCLEIC-CARD ${ }^{\mathrm{TM}}$ Collection Device System foram armazenadas em um lugar escuro, a temperatura ambiente, conforme indicações do fabricante. As amostras foram transportadas ao Brasil, para o processamento em parceria com a Faculdade de Odontologia de Bauru, Universidade de São Paulo - FOB/USP, no Laboratório de Fisiologia e Farmacologia Clínica.

\subsection{Processamento das amostras}

Foram feitos cortes de $1 \mathrm{~mm}$ nos cartões, com ajuda do picotador Fitzco ${ }^{\circledR}$ Classic Punch (Fitzco Inc. Minnesota, Estados Unidos) e colocados em placas de 96 poços (Applied Biosystems, São Paulo, Brasil). 
Para o processamento das amostras, foi utilizado o kit AmpFLSTR ${ }^{\circledR}$ Identifiler ${ }^{\circledR}$ Direct PCR Amplification (Life Technologies, Foster City, CA, USA), seguindo as instruções do fabricante. Esse kit facilita o processamento das amostras, pois a extração e purificação não são necessárias, avançando diretamente para as seguintes etapas de genotipagem, amplificação e sequenciamento, as quais serão descritas a seguir.

\subsubsection{Genotipagem PCR-STR}

A amplificação de 16 loci STR de DNA genômico, sendo 15 autossômicos polimórficos e a amelogenina, foi feita pelo método de PCR multiplex, utilizando o sistema AmpFLSTR ${ }^{\text {TM }}$ Identifiler ${ }^{\mathrm{TM}}$ Direct PCR Amplification Kit (Life Technologies, Foster City, CA, USA), conforme protocolo do fabricante. Este kit foi validado para tal finalidade de acordo com as normas do Grupo de Trabalho Científico sobre Métodos de Análise de DNA (SWGDAM) e diretrizes do FBI.

Os 16 loci amplificados contemplam o núcleo CODIS (Federal Bureau of Investigation, USA) e foram: D3S1358, vWA, FGA, D8S1179, D21S11, D18S51, D5S818, D13S317, D7S820, TH01, TPOX, CSF1PO, D19S433, D2S1338, D16S539 e o marcador de gênero, a amelogenina. Foram seguidos os protocolos do guia do usuário desse kit (Figura 4).

Figura 4 - Composição do AmpFISTR® Identifiler $囚$ Direct PCR Amplification Kit.

\begin{tabular}{|c|c|c|c|c|}
\hline $\begin{array}{l}\text { Locus } \\
\text { designation }\end{array}$ & $\begin{array}{l}\text { Chromosome } \\
\text { location }\end{array}$ & Alleles included in Allelic Ladder & Dye label & $\begin{array}{l}\text { Control } \\
\text { DNA 9947A }\end{array}$ \\
\hline D8S1179 & 8 & $8,910,11,12,13,14,15,16,17,18,19$ & \multirow[t]{4}{*}{ 6-FAM ${ }^{\top M}$} & 13,13 \\
\hline D21S11 & $21 q 11.2-q 21$ & $\begin{array}{l}24,24.2,25,26,27,28,28.2,29,29.2,30,30.2,31 \\
31.2,32,32.2,33,33.2,34,34.2,35,35.2,36,37,38\end{array}$ & & 30,30 \\
\hline D7S820 & $7 q 11.21-22$ & $6,7,8,9,10,11,12,13,14,15$ & & 10,11 \\
\hline CSF1PO & $5 q 33.3-34$ & $6,7,8,9,10,11,12,13,14,15$ & & 10,12 \\
\hline D3S1358 & $3 p$ & $12,13,14,15,16,17,18,19$ & \multirow[t]{5}{*}{$\mathrm{VII} \odot$} & 14,15 \\
\hline TH01 & 11p15.5 & $4,5,6,7,8,9,9.3,10,11,13.3$ & & 8.9 .3 \\
\hline D13S317 & $13 q 22-31$ & $8,9,10,11,12,13,14,15$ & & 11,11 \\
\hline D16S539 & 16q24-qter & $5,8,9,10,11,12,13,14,15$ & & 11,12 \\
\hline $\mathrm{D} 2 \mathrm{~S} 1338$ & $2 q 35-37.1$ & $15,16,17,18,19,20,21,22,23,24,25,26,27,28$ & & 19,23 \\
\hline D19S433 & $19 q 12-13.1$ & $\begin{array}{l}9,10,11,12,12.2,13,13.2,14,14.2,15,15.2,16 \\
16.2,17,17.2\end{array}$ & \multirow[t]{4}{*}{$N^{\prime M}$} & 14,15 \\
\hline vWA & 12p12-pter & $11,12,13,14,15,16,17,18,19,20,21,22,23,24$ & & 17,18 \\
\hline TPOX & 2p23-2per & $6,7,8,9,10,11,12,13$ & & 8,8 \\
\hline D18S51 & $18 q 21.3$ & $\begin{array}{l}7,9,10,10.2,11,12,13,13.2,14,14.2,15,16,17 \\
18,19,20,21,22,23,24,25,26,27\end{array}$ & & 15,19 \\
\hline Amelogenin & $X: p 22.1-22.3 ; Y: p 11.2$ & $X, Y$ & \multirow[t]{3}{*}{$\mathrm{PET}^{\circledR}$} & $x$ \\
\hline D5S818 & $5 q 21-31$ & $7,8,9,10,11,12,13,14,15,16$ & & 11,11 \\
\hline FGA & $4 \mathrm{q} 28$ & $\begin{array}{l}17,18,19,20,21,22,23,24,25,26,26.2,27,28 \\
29,30,30.2,31.2,32.2,33.2,42.2,43.2,44.2,45.2 \\
46.2,47.2,48.2,50.2,51.2\end{array}$ & & 23,24 \\
\hline
\end{tabular}

Fonte: Life Technologies, Foster City, CA, USA. Disponível em: https://www.thermofisher.com/order/catalog/product/4467831 


\subsubsection{Amplificação}

As reações de amplificação por PCR foram preparadas contendo $6,25 \mu \mathrm{L}$ de mistura de AmpFLSTR ${ }^{\mathrm{TM}}$ Identifiler ${ }^{\mathrm{TM}}$ Direct PCR Amplification STR Plus Master Mix com 6,25 $\mu \mathrm{L}$ de Primer Set, totalizando o volume final de 12,5 $\mu \mathrm{L}$ que foram colocados em cada poço da placa e acrescido de $1 \mathrm{~mm}$ do cartão de coleta de saliva com DNA.

As amostras foram amplificadas em placas de 96 poços (Applied Biosystems, São Paulo, Brasil) no GeneAmp Veriti (Applied Biosystems, São Paulo, Brasil). As condições de ciclos térmicos padrão constituíram em: ativação da enzima a $95^{\circ} \mathrm{C}$ durante 11 minutos; 26 ciclos de desnaturação a $94^{\circ} \mathrm{C}$ durante 20 segundos, anelamento a $59^{\circ} \mathrm{C}$ por 2 minutos; e extensão a $72^{\circ} \mathrm{C}$ por 1 minuto. O último passo foi realizado a $60^{\circ} \mathrm{C}$ durante 25 minutos para estabilizar o produto resultante desse processo, denominado produto da PCR, que será mantido a $4^{\circ} \mathrm{C}$ até o próximo passo.

\subsubsection{Eletroforese capilar}

Foram seguidos os protocolos do Guia do Usuário do Kit AmpFLSTR TM Identifiler ${ }^{\mathrm{TM}}$ Direct PCR Amplification Kit (Life Technologies, Foster City, CA, USA). As amostras foram preparadas por adição de $1 \mu \mathrm{L}$ do produto da PCR para $9 \mu \mathrm{L}$ de solução de formamida / LIZ® $\left(0,3 \mu \mathrm{L}\right.$ de GeneScan ${ }^{\mathrm{TM}} 600 \mathrm{LIZ}^{\circledR}$ de tamanho padrão e 8,7 $\mu \mathrm{L}$ de formamida deionizada (Hi-DlTM; Applied Biosystems, São Paulo, Brasil). Antes da eletroforese, as amostras foram desnaturadas a $95^{\circ} \mathrm{C}$ durante 5 minutos, em seguida mergulhadas no gelo durante 5 minutos. Utilizando o sequenciador Applied Biosystems 3130xl Genetic Analyzer, as amostras foram injetadas através de 16 capilares de $36 \mathrm{~cm}$ a $3 \mathrm{kV}$ durante 10 segundos e submetidas a eletroforese a $15 \mathrm{kV}$ durante 15 segundos em polímero optimizado-4 (POP-4 ${ }^{\mathrm{TM}}$ Applied Biosystems, São Paulo, Brasil) a $60^{\circ} \mathrm{C}$.

A seguir, os dados resultantes da eletroforese, os eletroferogramas, foram analisados pelo programa GeneMapper ID-X 1.4 (Applied Biosystems, São Paulo, Brasil). Os picos alélicos foram interpretados quando as suas alturas forem $\geq 50$ unidades de fluorescência relativa (RFU). 


\subsection{Análise estatística}

A análise de equilíbrio de Hardy-Weinberg foi realizada para cada locus pelo teste exato, utilizando o software Arlequin 3.5. As frequências alélicas, os parâmetros forenses incluindo a heterozigosidade observada $(\mathrm{HO})$, heterozigosidade esperada (HE), o poder de discriminação (PD), probabilidade de matching (MP), o conteúdo de informação polimórfica (PIC) e o poder de exclusão (PE) dos loci foram calculados pelos softwares GenAlEx 6.5 (PEAKALL; SMOUSE 2006, 2012) e Arlequin 3.5 (EXCOFFIER; LISCHER, 2010).

Foram comparados os dados genotípicos obtidos em esta pesquisa, com quatro populações dos Estados Unidos; Hispanos, Caucasianos, Afro americanos e Asiáticos (COBLE; HILL; BUTLER, 2013; HILL et al., 2013; BUTLER; HILL; COBLE, 2012) utilizando o método da análise da variância molecular (AMOVA, com base em estatística-F) com o software Arlequin 3.5 Além disso, utilizando o mesmo programa, foi calculado o coeficiente de consanguinidade (Fis), coeficiente de consanguinidade total (Fit) e índice de fixação total (Fst), contemplando as analises de variação entre as pessoas, dentro de cada população e entre as cinco populações estudadas.

\section{RESULTADOS}

Das 300 amostras coletadas, foi possível estabelecer o perfil genético de 259 amostras, sendo 130 do sexo feminino e 129 do sexo masculino.

No software GeneMapper ID-X 1.4, foram observados os picos alélicos nos marcadores genéticos estudados das 259 amostras, as quais têm sido interpretadas quando as suas alturas forem $\geq 50$ unidades de fluorescência relativa e posteriormente exportados em uma tabela de Excel para análise. (Tabela 2).

A Figura 5 ilustra o eletroferograma ideal com o perfil genético dos 16 diferentes loci analisados (15 STR e AMEL). A barra verde indica a qualidade ideal do experimento. Já a Figura 6 ilustra um eletroferograma aceitável, onde as cores amarelas propõem uma advertência e recomendam uma avaliação cuidadosa. Em alguns casos onde o motivo da advertência foi justificado, foi realizada uma modificação manual. Elas foram efetuadas unicamente quando os alelos se encontravam claramente identificáveis e confirmou-se algum erro de 
leitura referente a estouro de sinal decorrente, por exemplo, de um marcador homozigoto localizado no mesmo bin, só que de outro marcador.

Figura 5 - Eletroferograma ideal ilustrando os 16 STR dos 16 diferentes loci analisados (15 STR e AMEL). A coloração verde indicando a qualidade ideal do experimento.



Fonte: GeneMapper software. Applied Biosystems, São Paulo, Brasil.

Figura 6 - Eletroferograma aceitável ilustrando os 16 STR dos 16 diferentes loci analisados (15 STR e AMEL). A coloração amarela recomendando uma avaliação cuidadosa.

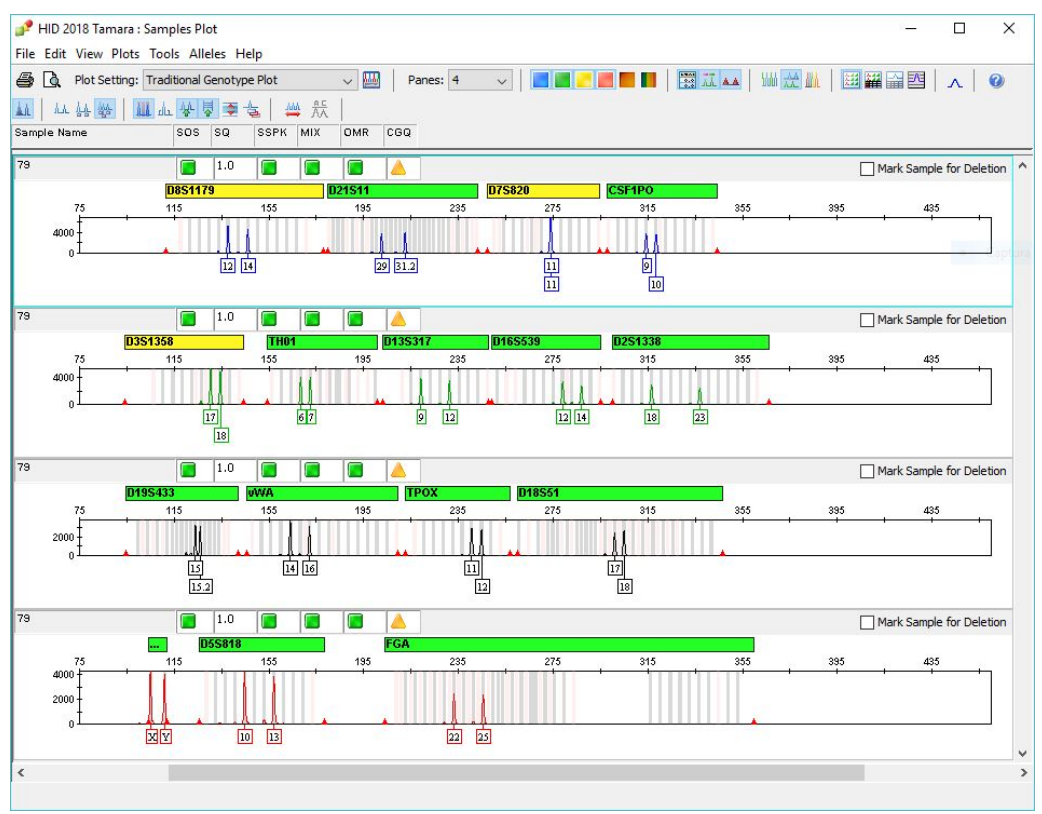

Fonte: GeneMapper software. Applied Biosystems, São Paulo, Brasil 
Na Figura 7 observamos um eletroferograma não aceitável onde a barra vermelha indica uma baixa qualidade, podendo ser resultante de contaminação, falta de DNA na amostra analisada, erro de leitura, etc. Todas as amostras que apresentaram estas caraterísticas foram processadas novamente até obter minimamente uma qualidade aceitável. A Tabela 2 exemplifica de forma didática, os alelos presentes nos marcadores estudados das amostras 1-5. Isso foi realizado para as 259 amostras.

Figura 7 - Eletroferograma não aceitável. A coloração vermelha indicando a necessidade de refazer o processamento da amostra.

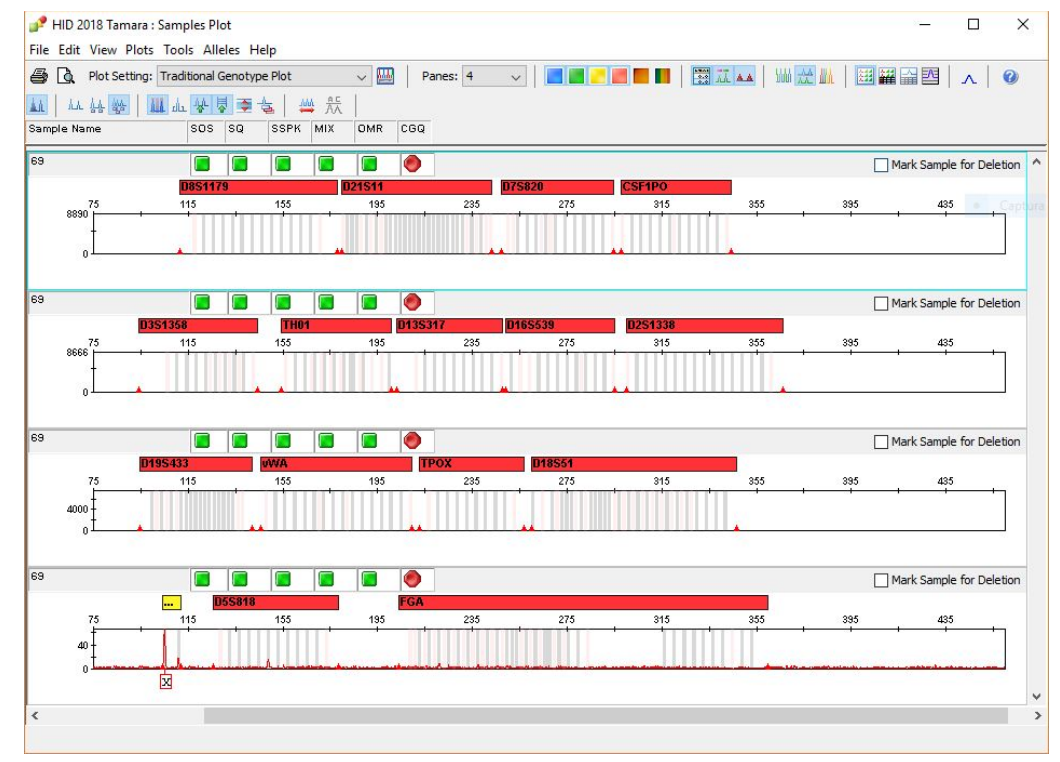

Fonte: GeneMapper software. Applied Biosystems, São Paulo, Brasil.

Tabela 2 - Alelos presentes nos marcadores estudados das amostras 1-5.

\begin{tabular}{ccccccccccc}
\hline \multirow{2}{*}{ MARCADOR } & \multicolumn{2}{c}{ Amostra 1 } & \multicolumn{2}{c}{ Amostra 2 } & \multicolumn{2}{c}{ Amostra 3 } & \multicolumn{2}{c}{ Amostra 4 } & \multicolumn{2}{c}{ Amostra 5 } \\
& A.1 & A.2 & A.1 & A.2 & A.1 & A.2 & A.1 & A.2 & A.1 & A.2 \\
\hline D8S1179 & 11 & 14 & 13 & 13 & 13 & 13 & 10 & 16 & 10 & 16 \\
D21S11 & 28 & 30 & 28 & 29 & 29 & 31 & 31 & 32.2 & 31 & 32.2 \\
D7S820 & 10 & 13 & 10 & 11 & 9 & 12 & 8 & 12 & 8 & 12 \\
CSF1PO & 12 & 13 & 10 & 12 & 10 & 14 & 11 & 12 & 11 & 12 \\
D3S1358 & 16 & 18 & 14 & 16 & 15 & 16 & 15 & 16 & 15 & 16 \\
TH01 & 7 & 7 & 7 & 9 & 7 & 7 & 6 & 9.3 & 6 & 9.3 \\
D13S317 & 13 & 14 & 9 & 11 & 11 & 12 & 12 & 13 & 12 & 13 \\
D16S539 & 9 & 9 & 10 & 11 & 11 & 12 & 12 & 13 & 12 & 13 \\
D2S1338 & 17 & 22 & 17 & 21 & 17 & 17 & 17 & 23 & 17 & 23 \\
D19S433 & 13 & 13 & 15 & 16 & 14 & 15.2 & 13 & 13.2 & 13 & 13.2 \\
vWA & 14 & 16 & 14 & 17 & 15 & 16 & 18 & 21 & 18 & 21 \\
TPOX & 11 & 11 & 9 & 12 & 8 & 11 & 8 & 12 & 8 & 12 \\
D18S51 & 14 & 15 & 12 & 14 & 13 & 15 & 12 & 15 & 12 & 15 \\
AMEL & $\mathrm{X}$ & $\mathrm{Y}$ & $\mathrm{X}$ & $\mathrm{Y}$ & $\mathrm{X}$ & $\mathrm{Y}$ & $\mathrm{X}$ & $\mathrm{X}$ & $\mathrm{X}$ & $\mathrm{X}$ \\
D5S818 & 11 & 13 & 11 & 12 & 11 & 12 & 11 & 11 & 11 & 11 \\
FGA & 20 & 24 & 21 & 21 & 21 & 24 & 21 & 22 & 21 & 22 \\
\hline
\end{tabular}


A Tabela 3 apresenta, para cada locus analisado, a faixa de variação dos alelos, os números de alelos obtidos em cada locus, os alelos mais e os menos frequentes. Os loci mais polimórficos na população paraguaia foram FGA, D18S51, D19S433, D21S11, D2S1338 com 17,14,13,14 e 11 diferentes alelos respectivamente.

Tabela 3 - Faixa de variação de alelos, números de alelos (N.A), os de maior e menor frequência em cada loci estudado excluindo o marcador de género AMEL.

\begin{tabular}{|c|c|c|c|c|c|c|}
\hline \multirow{2}{*}{$\mathrm{LOCl}$} & \multirow{2}{*}{$\begin{array}{l}\text { VARIAÇÃO DE } \\
\text { ALELOS }\end{array}$} & \multirow{2}{*}{ N.A } & \multicolumn{2}{|c|}{ ALELOS >FREQ. } & \multicolumn{2}{|c|}{ ALELOS < FREQ } \\
\hline & & & Alelo & Frequência & Alelo & Frequência \\
\hline \multirow{2}{*}{ D8S1179 } & \multirow{2}{*}{$8-17$} & \multirow{2}{*}{10} & 13 & 0,284 & 17 & 0,002 \\
\hline & & & 14 & 0,278 & 9 & 0,004 \\
\hline \multirow{2}{*}{ D21S11 } & \multirow{2}{*}{$25,2-34,2$} & \multirow{2}{*}{14} & 30 & 0,278 & 25,2 & 0,002 \\
\hline & & & 29 & 0,187 & 29,2 & 0,002 \\
\hline \multirow{2}{*}{ D7S820 } & \multirow{2}{*}{$7-14$} & \multirow{2}{*}{9} & 11 & 0,290 & 9,1 & 0,002 \\
\hline & & & 10 & 0,228 & 14 & 0,002 \\
\hline \multirow{2}{*}{ CSF1PO } & \multirow{2}{*}{$7-14$} & \multirow{2}{*}{8} & 12 & 0,371 & 7 & 0,002 \\
\hline & & & 11 & 0,276 & 8 & 0,008 \\
\hline \multirow{2}{*}{ D3S1358 } & \multirow{2}{*}{ 12- 19} & \multirow{2}{*}{8} & 15 & 0,311 & 13 & 0,004 \\
\hline & & & 16 & 0,282 & 12 & 0,006 \\
\hline \multirow{2}{*}{ TH01 } & \multirow{2}{*}{$6-10$} & \multirow{2}{*}{6} & 6 & 0,286 & 10 & 0,010 \\
\hline & & & 7 & 0,261 & 8 & 0,104 \\
\hline \multirow{2}{*}{ D13S317 } & \multirow{2}{*}{$8-14$} & \multirow{2}{*}{7} & 12 & 0,255 & 10 & 0,054 \\
\hline & & & 11 & 0,237 & 8 & 0,073 \\
\hline \multirow{2}{*}{ D16S539 } & \multirow{2}{*}{$8-14$} & \multirow{2}{*}{7} & 12 & 0,303 & 8 & 0,019 \\
\hline & & & 11 & 0,249 & 14 & 0,029 \\
\hline \multirow{2}{*}{ D2S1338 } & $16-26$ & 11 & 17 & 0,230 & 26 & 0,004 \\
\hline & $10-\angle 6$ & 11 & 23 & 0,127 & 21 & 0,031 \\
\hline D19S433 & $10-162$ & 13 & 14 & 0,305 & 10 & 0,002 \\
\hline & & & 13 & 0,212 & 11,2 & 0,002 \\
\hline 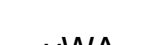 & $10 \Omega$ & 0 & 17 & 0,332 & 13 & 0,002 \\
\hline 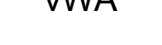 & $10-21$ & $y$ & 16 & 0,266 & 20 & 0,004 \\
\hline TPO1 & $6-13$ & 8 & 8 & 0,452 & 13 & 0,002 \\
\hline ו ו & $0-13$ & 0 & 11 & 0,282 & 6 & 0,004 \\
\hline D18S51 & $10-23$ & 14 & 14 & 0,222 & 23 & 0,002 \\
\hline & & & 15 & 0,158 & 21 & 0,004 \\
\hline D5S818 & $7-14$ & 8 & 11 & 0,456 & 14 & 0,002 \\
\hline & $1-14$ & 0 & 12 & 0,259 & 8 & 0,004 \\
\hline$F G A$ & $17-30$ & 17 & 24 & 0,166 & 17 & 0,002 \\
\hline & & 16 & 21 & 0,151 & 20,2 & 0,002 \\
\hline
\end{tabular}

As figuras 8-22 expõem as diferentes frequências alélicas para cada loci analisado. A Tabela 4 apresenta a distribuição das frequências alélicas dos 259 indivíduos paraguaios, dos 15 loci autossômicos analisados bem como os 
parâmetros forenses, calculados utilizando os programas GenAIEx 6.5 (PEAKALL; SMOUSE 2006, 2012) e Arlequin 3.5 (EXCOFFIER; LISCHER, 2010).

O locus AMEL foi desconsiderado na análise de frequência por não apresentar relevância. Alelos com frequência alélica dentre 0,05 e 0,25 são considerados de baixa frequência, entretanto aqueles com frequência menor que 0,05 são considerados raros.

Figura 8 - Frequência alélica do Locus D8S1179 exportada do software GenAIEx 6.5 na amostra estudada.

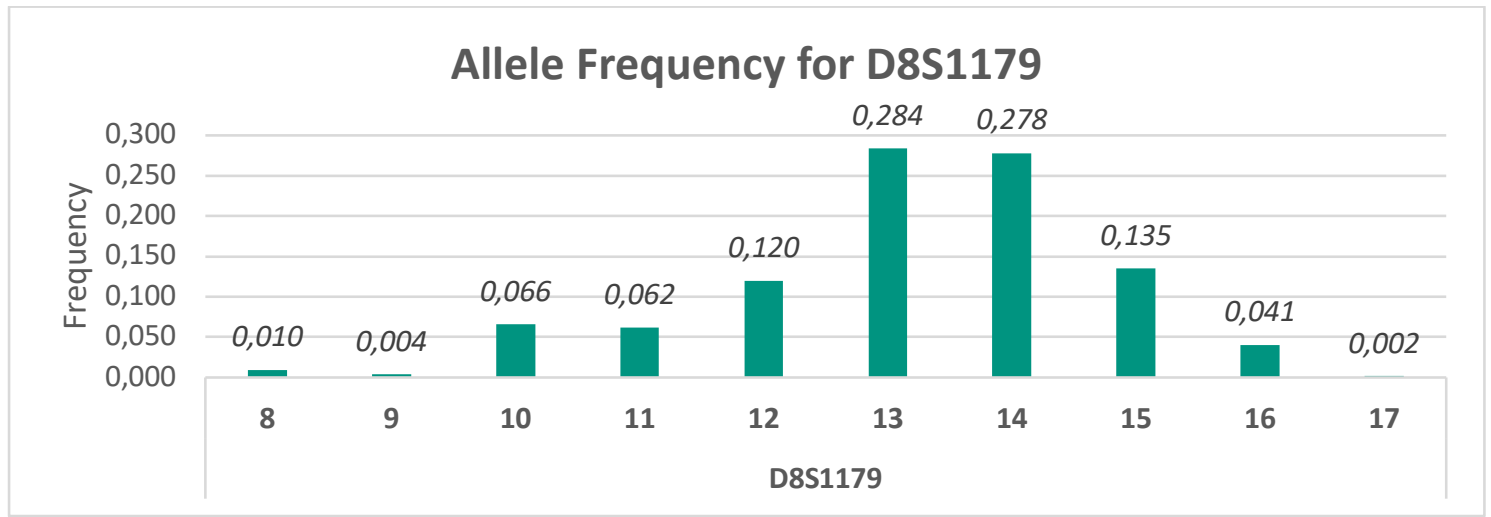

Figura 9 - Frequência alélica do Locus D21S11 gerada pelo software GenAIEx 6.5 na amostra estudada.

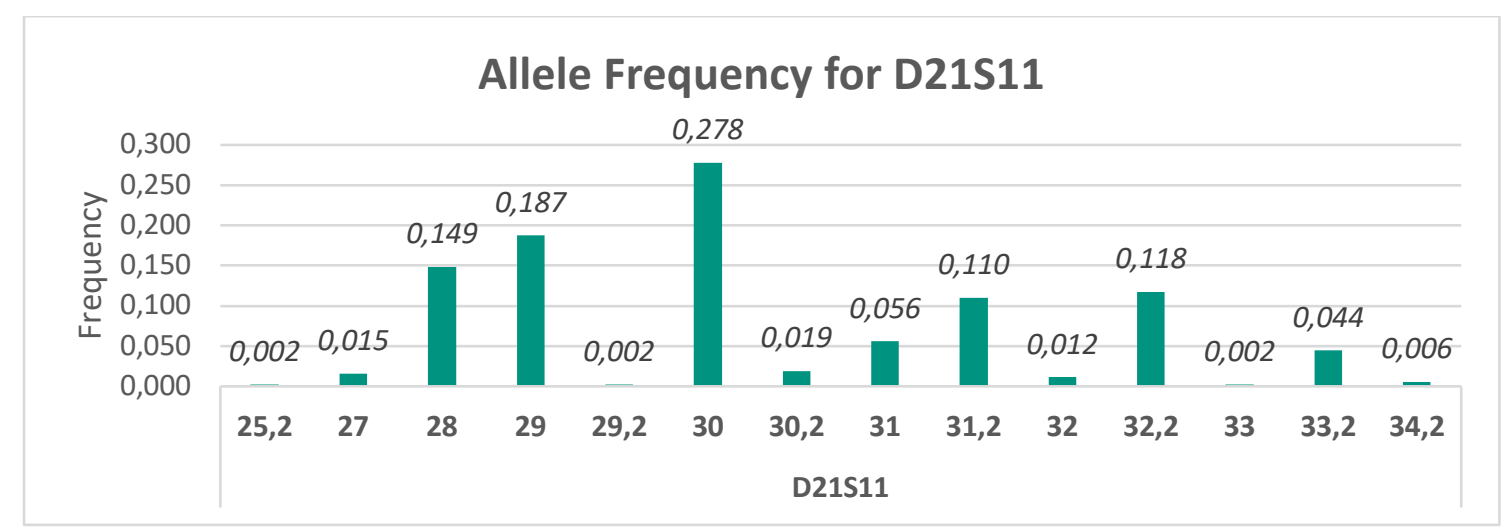


Figura 10 - Frequência alélica do Locus D7S820 gerada pelo software GenAIEx 6.5 na amostra estudada.

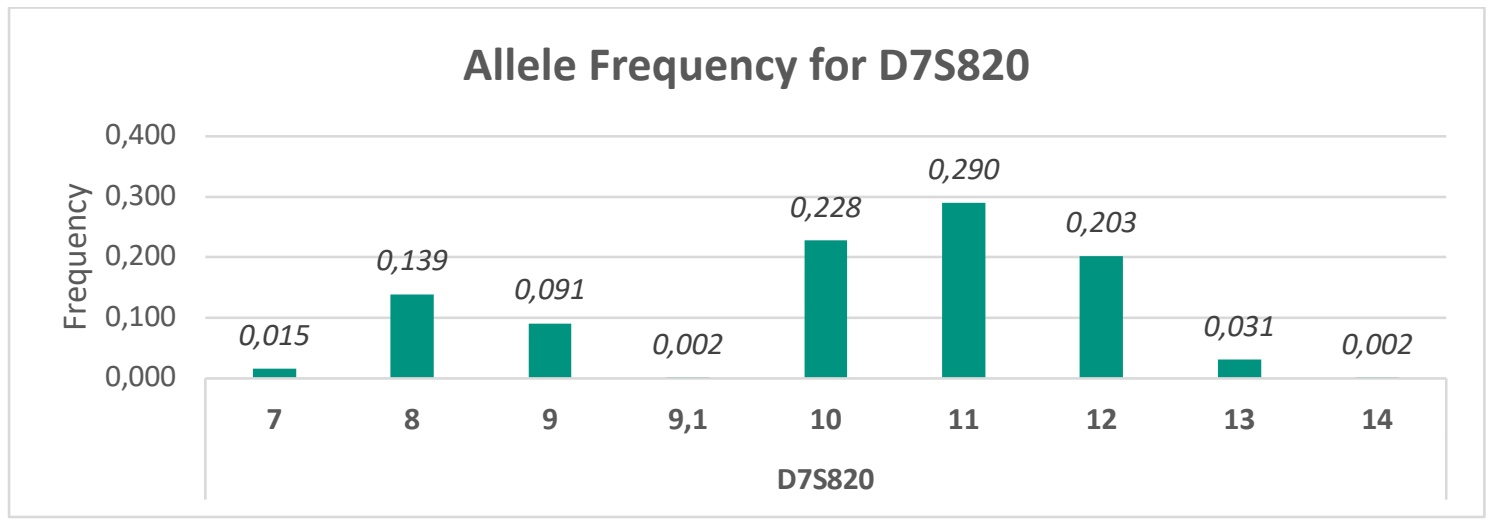

Figura 11 - Frequência alélica do Locus CSF1PO gerada pelo software GenAlEx 6.5 na amostra estudada.

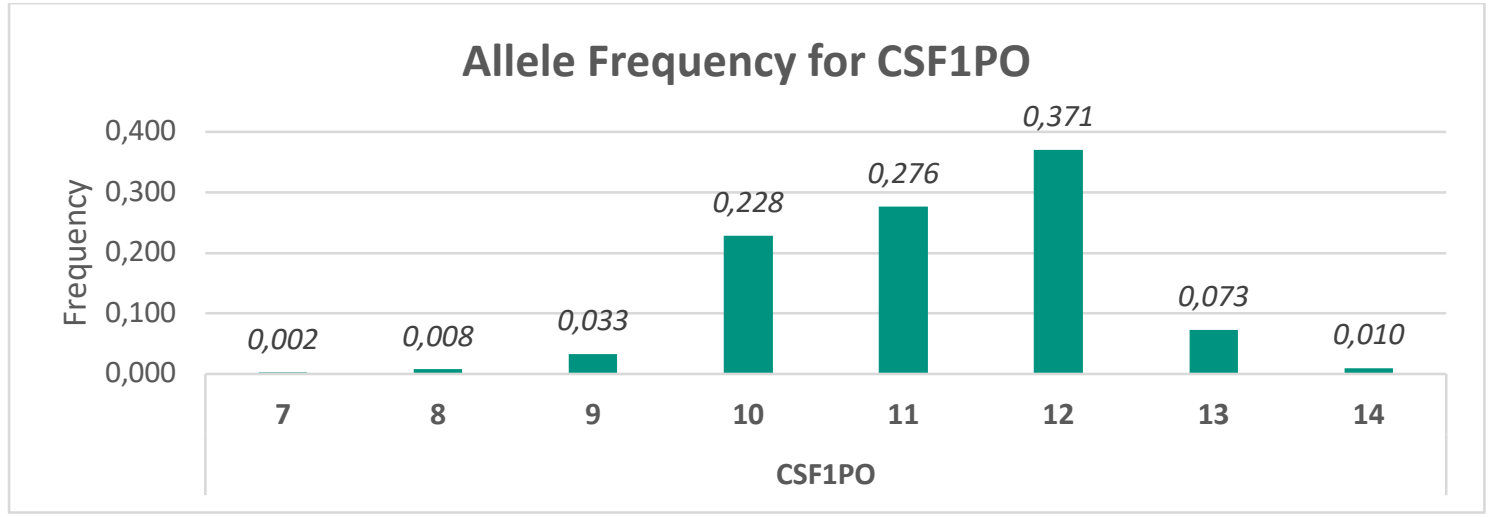

Figura 12 - Frequência alélica do Locus D3S1358 gerada pelo software GenAIEx 6.5 na amostra estudada.

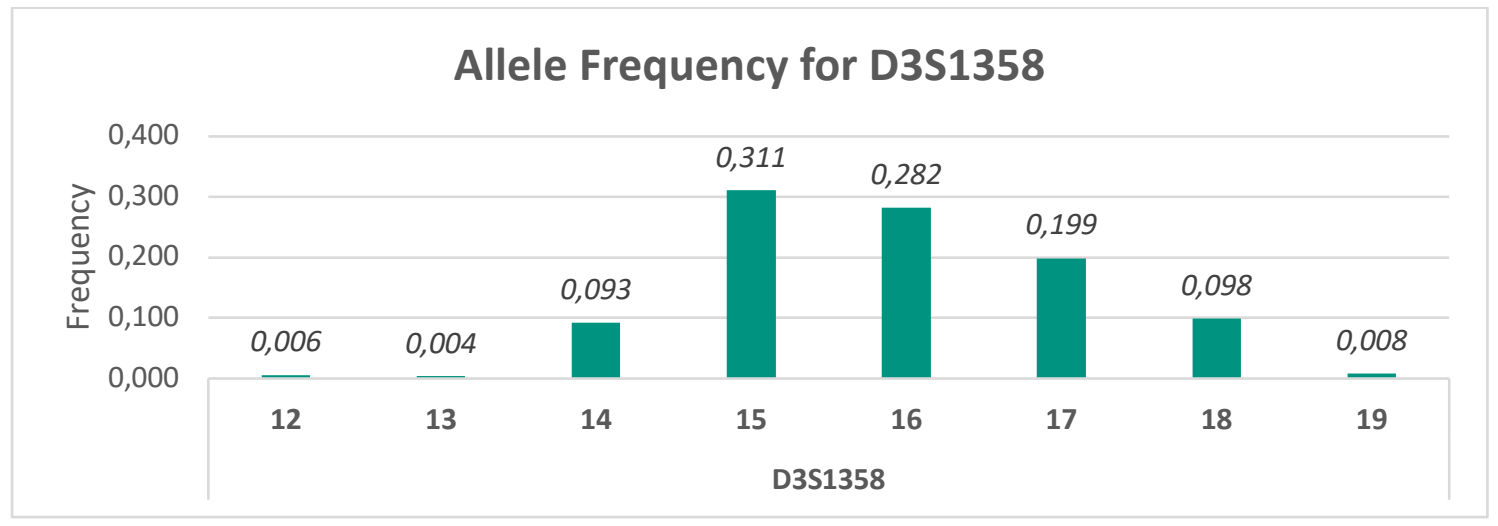


Figura 13 - Frequência alélica do Locus TH01 gerada pelo software GenAIEx 6.5 na amostra estudada.

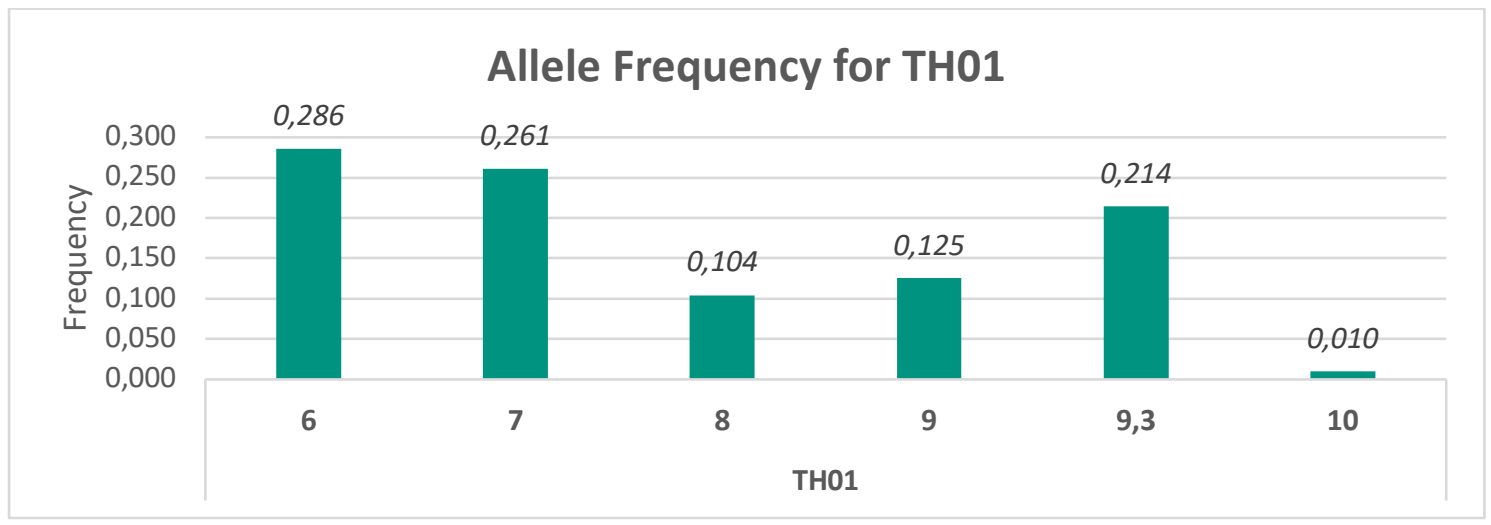

Figura 14 - Frequência alélica do Locus D13S317 gerada pelo software GenAIEx 6.5 na amostra estudada.

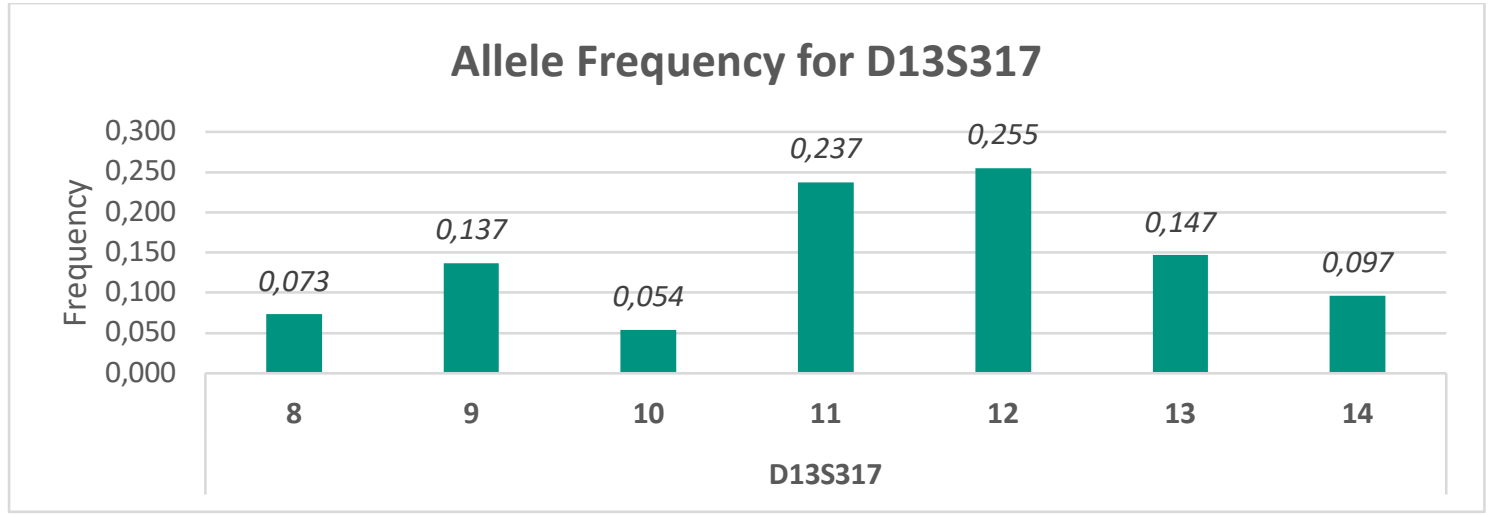

Figura 15 - Frequência alélica do Locus D16S539 gerada pelo software GenAIEx 6.5 na amostra estudada.

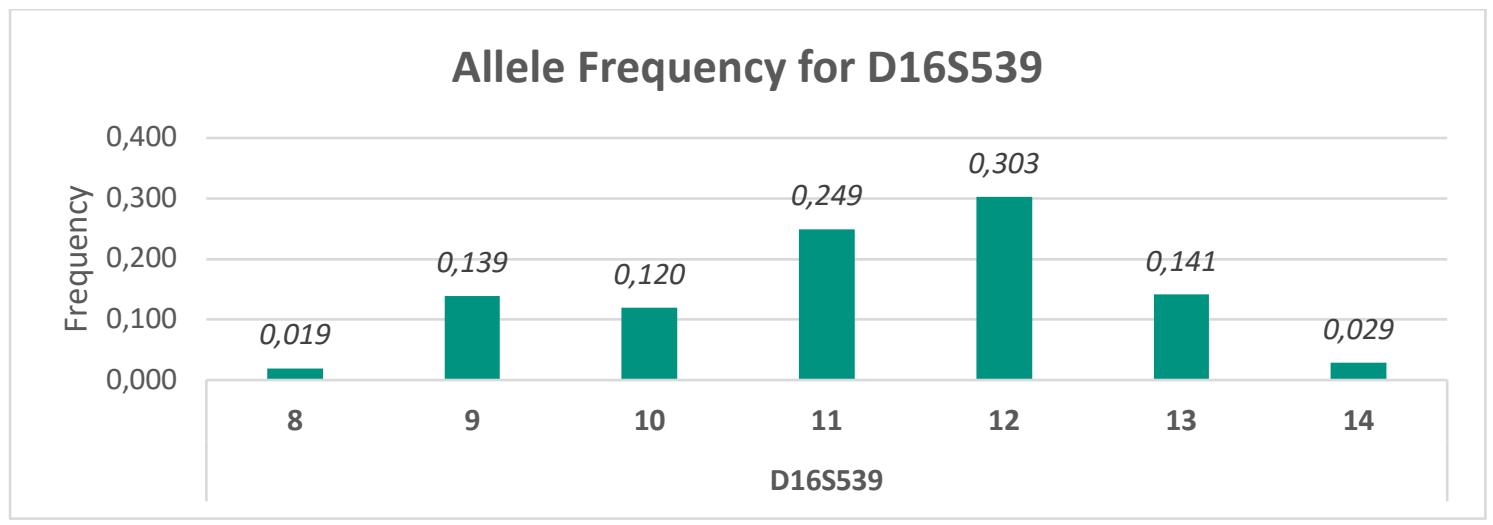


Figura 16 - Frequência alélica do Locus D2S1338 gerada pelo software GenAlEx 6.5 na amostra estudada.



Figura 17 - Frequência alélica do Locus D19S433 gerada pelo software GenAIEx 6.5 na amostra estudada.

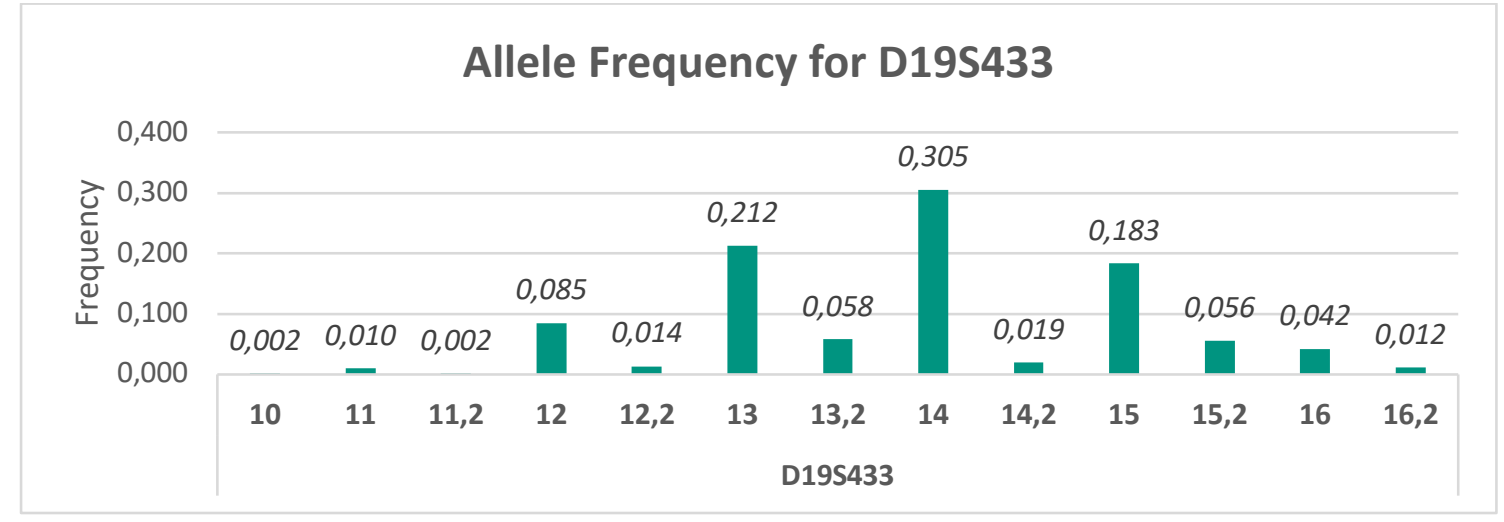

Figura 18 - Frequência alélica do Locus vWA gerada pelo software GenAIEx 6.5 na amostra estudada.

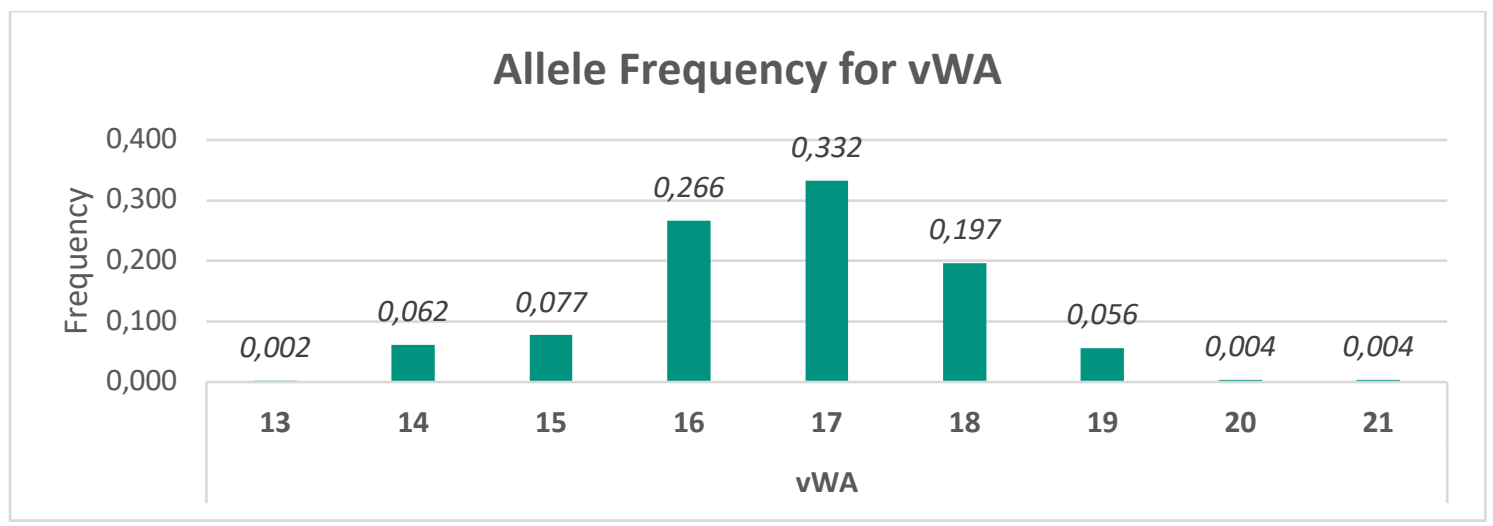


Figura 19 - Frequência alélica do Locus TPOX gerada pelo software GenAIEx 6.5 na amostra estudada.

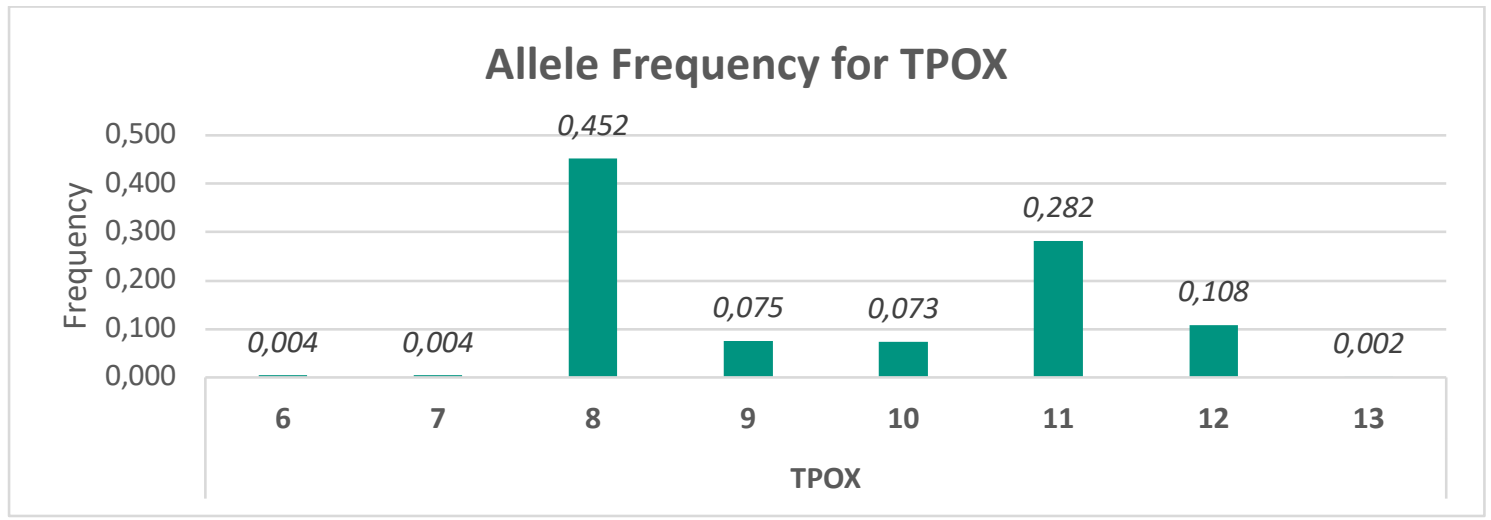

Figura 20 - Frequência alélica do Locus D18S51 gerada pelo software GenAIEx 6.5 na amostra estudada.

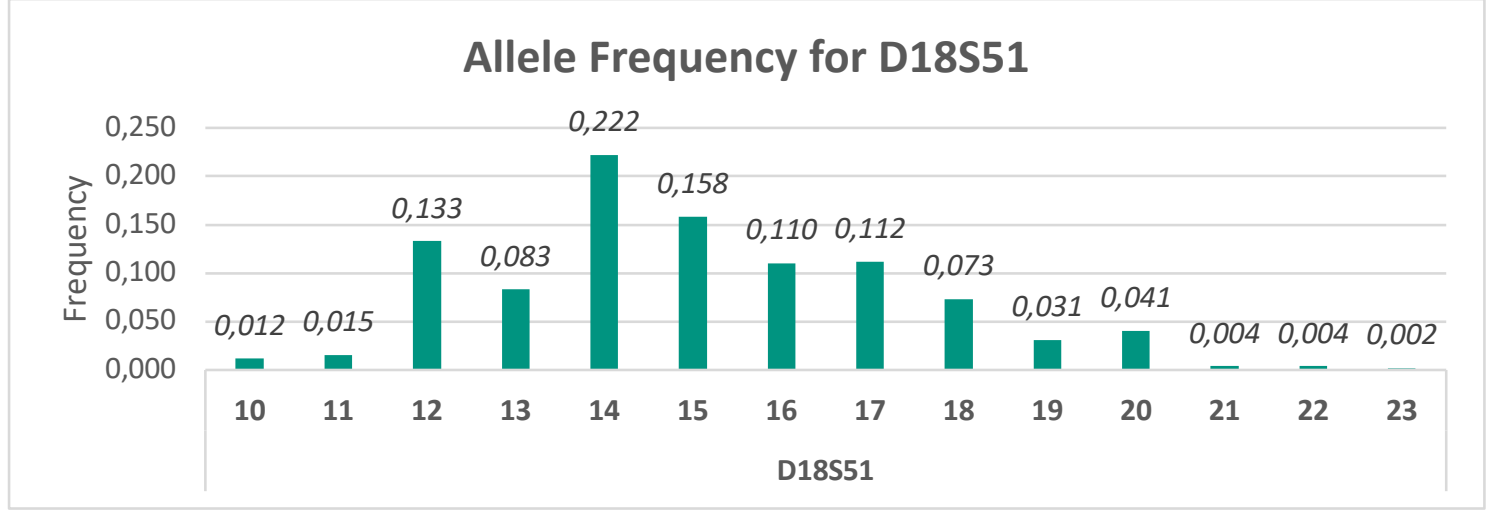

Figura 21 - Frequência alélica do Locus D5S818 gerada pelo software GenAIEx 6.5 na amostra estudada.

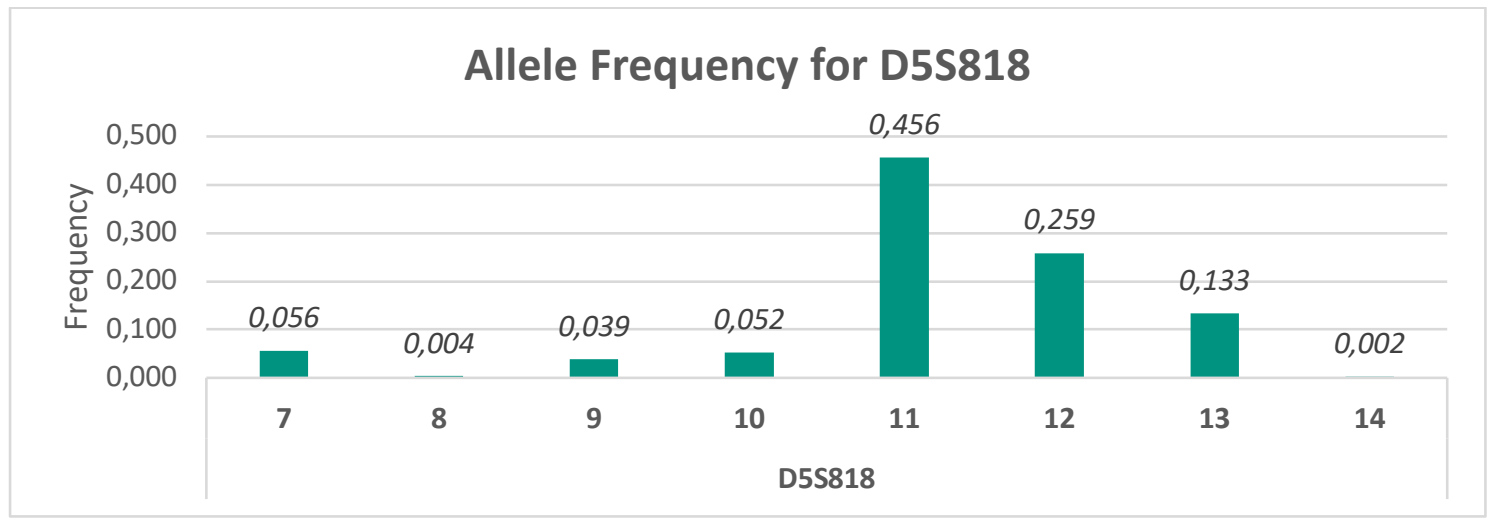


Figura 22 - Frequência alélica do Locus FGA gerada pelo software GenAIEx 6.5 na amostra estudada.

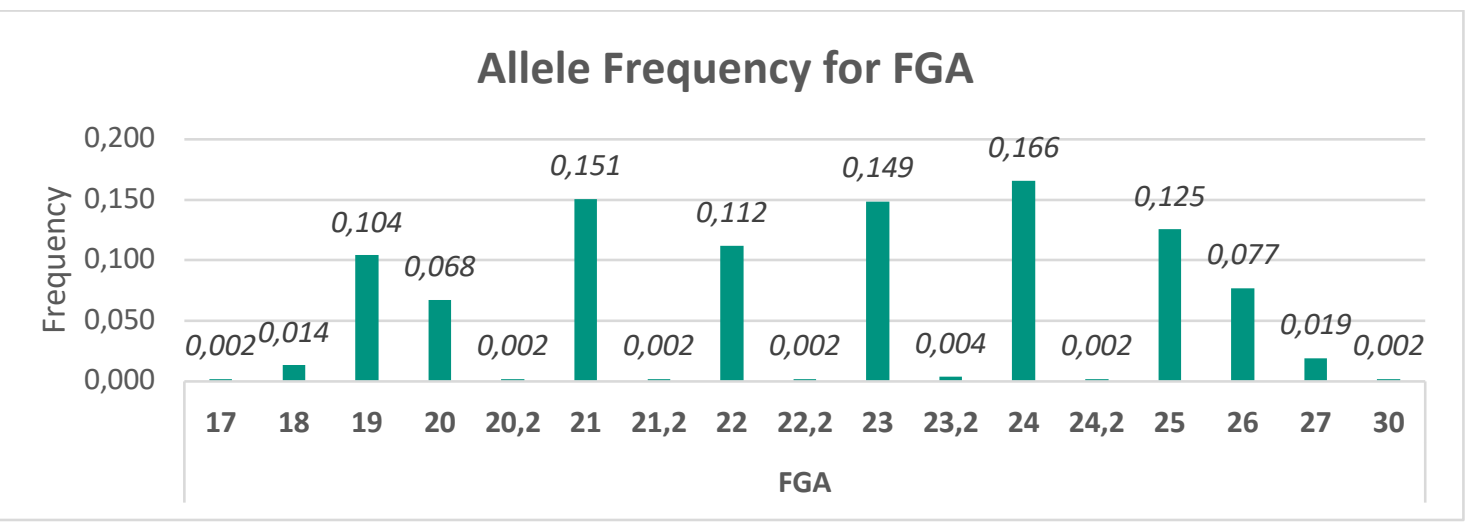

A Tabela 5 apresenta os resultados realizados para o cálculo do equilíbrio de Hardy-Weinberg, aplicando o teste exato utilizando o software Arlequin 3.5 (EXCOFFIER; LISCHER, 2010), onde o nível de significância mostra os loci que apresentaram valores maiores a 0.05 (não significantes) e menores a 0.05 (significantes).

$\mathrm{Na}$ amostra populacional analisada foi possível verificar que a maioria das frequências genotípicas estão distribuídas de acordo com o esperado, portanto encontram-se em equilíbrio de Hardy-Weinberg, com exceção dos loci FGA e CSF1PO os quais apresentaram valores de $\mathrm{P}=0,01$. 
Tabela 4 - Distribuição das frequências alélicas dos 259 indivíduos paraguaios incluindo dos parâmetros forenses.

\begin{tabular}{|c|c|c|c|c|c|c|c|c|c|c|c|c|c|c|c|}
\hline ALLELE & D8S1179 & D21S11 & D7S820 & CSF1PO & D3S1358 & TH01 & D13S317 & D16S539 & D2S1338 & D19S433 & vWA & TPOX & D18S51 & D5S818 & FGA \\
\hline 6 & - & - & - & - & - & 0,286 & - & - & - & - & - & 0,004 & - & - & - \\
\hline 7 & - & - & 0,015 & 0,002 & - & 0,261 & - & - & - & - & - & 0,004 & - & 0,056 & - \\
\hline 8 & 0,010 & - & 0,139 & 0,008 & - & 0,104 & 0,073 & 0,019 & - & - & - & 0,452 & - & 0,004 & - \\
\hline 9 & 0,004 & - & 0,091 & 0,033 & - & 0,125 & 0,137 & 0,139 & - & - & - & 0,075 & - & 0,039 & - \\
\hline 9,1 & - & - & 0,002 & - & - & - & - & - & - & - & - & - & - & - & - \\
\hline 9,3 & - & - & - & - & - & 0,214 & - & - & - & - & - & - & - & - & - \\
\hline 10 & 0,066 & - & 0,228 & 0,228 & - & 0,010 & 0,054 & 0,120 & - & 0,002 & - & 0,073 & 0,012 & 0,052 & - \\
\hline 11 & 0,062 & - & 0,290 & 0,276 & - & - & 0,237 & 0,249 & - & 0,010 & - & 0,282 & 0,015 & 0,456 & - \\
\hline 11,2 & - & - & - & - & - & - & - & - & - & 0,002 & - & - & - & - & - \\
\hline 12 & 0,120 & - & 0,203 & 0,371 & 0,006 & - & 0,255 & 0,303 & - & 0,085 & - & 0,108 & 0,133 & 0,259 & - \\
\hline 12,2 & - & - & - & - & - & - & - & - & - & 0,014 & - & - & - & - & - \\
\hline 13 & 0,284 & - & 0,031 & 0,073 & 0,004 & - & 0,147 & 0,141 & - & 0,212 & 0,002 & 0,002 & 0,083 & 0,133 & - \\
\hline 13,2 & - & - & - & - & - & - & - & - & - & 0,058 & - & - & - & - & - \\
\hline 14 & 0,278 & - & 0,002 & 0,010 & 0,093 & - & 0,097 & 0,029 & - & 0,305 & 0,062 & - & 0,222 & 0,002 & - \\
\hline 14,2 & - & - & - & - & - & - & - & - & - & 0,019 & - & - & - & - & - \\
\hline 15 & 0,135 & - & - & - & 0,311 & - & - & - & - & 0,183 & 0,077 & - & 0,158 & - & - \\
\hline 15,2 & - & - & - & - & - & - & - & - & - & 0,056 & - & - & - & - & - \\
\hline 16 & 0,041 & - & - & - & 0,282 & - & - & - & 0,037 & 0,042 & 0,266 & - & 0,110 & - & - \\
\hline 16,2 & - & - & - & - & - & - & - & - & - & 0,012 & - & - & - & - & - \\
\hline 17 & 0,002 & - & - & - & 0,199 & - & - & - & 0,230 & - & 0,332 & - & 0,112 & - & 0,002 \\
\hline 18 & - & - & - & - & 0,098 & - & - & - & 0,120 & - & 0,197 & - & 0,073 & - & 0,014 \\
\hline 19 & - & - & - & - & 0,008 & - & - & - & 0,112 & - & 0,056 & - & 0,031 & - & 0,104 \\
\hline 20 & - & - & - & - & - & - & - & - & 0,122 & - & 0,004 & - & 0,041 & - & 0,068 \\
\hline 20,2 & - & - & - & - & - & - & - & - & - & - & - & - & - & - & 0,002 \\
\hline 21 & - & - & - & - & - & - & - & - & 0,031 & - & 0,004 & - & 0,004 & - & 0,151 \\
\hline 21,2 & - & - & - & - & - & - & - & - & - & - & - & - & - & - & 0,002 \\
\hline 22 & - & - & - & - & - & - & - & - & 0,087 & - & - & - & 0,004 & - & 0,112 \\
\hline 22,2 & - & - & - & - & - & - & - & - & - & - & - & - & - & - & 0,002 \\
\hline 23 & - & - & - & - & - & - & - & - & 0,127 & - & - & - & 0,002 & - & 0,149 \\
\hline
\end{tabular}




\begin{tabular}{|c|c|c|c|c|c|c|c|c|c|c|c|c|c|c|c|}
\hline 23,2 & - & - & - & - & - & - & - & - & - & - & - & - & - & - & 0,004 \\
\hline 24 & - & - & - & - & - & - & - & - & 0,079 & - & - & - & - & - & 0,166 \\
\hline 24,2 & - & - & - & - & - & - & - & - & - & - & - & - & - & - & 0,002 \\
\hline 25 & - & - & - & - & - & - & - & - & 0,052 & - & - & - & - & - & 0,125 \\
\hline 25,2 & - & 0,002 & - & - & - & - & - & - & - & - & - & - & - & - & - \\
\hline 26 & - & - & - & - & - & - & - & - & 0,004 & - & - & - & - & - & 0,077 \\
\hline 27 & - & 0,015 & - & - & - & - & - & - & - & - & - & - & - & - & 0,019 \\
\hline 28 & - & 0,149 & - & - & - & - & - & - & - & - & - & - & - & - & - \\
\hline 29 & - & 0,187 & - & - & - & - & - & - & - & - & - & - & - & - & - \\
\hline 29,2 & - & 0,002 & - & - & - & - & - & - & - & - & - & - & - & - & - \\
\hline 30 & - & 0,278 & - & - & - & - & - & - & - & - & - & - & - & - & 0,002 \\
\hline 30,2 & - & 0,019 & - & - & - & - & - & - & - & - & - & - & - & - & - \\
\hline 31 & - & 0,056 & - & - & - & - & - & - & - & - & - & - & - & - & - \\
\hline 21,2 & - & 0,110 & - & - & - & - & - & - & - & - & - & - & - & - & - \\
\hline 32 & - & 0,012 & - & - & - & - & - & - & - & - & - & - & - & - & - \\
\hline 32,2 & - & 0,118 & - & - & - & - & - & - & - & - & - & - & - & - & - \\
\hline 33 & - & 0,002 & - & - & - & - & - & - & - & - & - & - & - & - & - \\
\hline 33,2 & - & 0,044 & - & - & - & - & - & - & - & - & - & - & - & - & - \\
\hline 34,2 & - & 0,006 & - & - & - & - & - & - & - & - & - & - & - & - & - \\
\hline HO & 0,815 & 0,807 & 0,807 & 0,749 & 0,811 & 0,757 & 0,807 & 0,730 & 0,857 & 0,784 & 0,749 & 0,718 & 0,892 & 0,734 & 0,896 \\
\hline HE & 0,800 & 0,834 & 0,794 & 0,728 & 0,766 & 0,778 & 0,821 & 0,791 & 0,870 & 0,812 & 0,767 & 0,694 & 0,868 & 0,700 & 0,877 \\
\hline MP & 0,073 & 0,139 & 0,082 & 0,126 & 0,104 & 0,145 & 0,057 & 0,072 & 0,032 & 0,112 & 0,092 & 0,148 & 0,034 & 0,134 & 0,034 \\
\hline PD & 0,927 & 0,861 & 0,918 & 0,874 & 0,896 & 0,855 & 0,943 & 0,928 & 0,968 & 0,888 & 0,908 & 0,852 & 0,966 & 0,866 & 0,966 \\
\hline PIC & 0,773 & 0,653 & 0,763 & 0,681 & 0,729 & 0,647 & 0,797 & 0,761 & 0,857 & 0,697 & 0,732 & 0,648 & 0,854 & 0,659 & 0,861 \\
\hline PE & 0,613 & 0,674 & 0,596 & 0,488 & 0,548 & 0,564 & 0,645 & 0,593 & 0,741 & 0,638 & 0,555 & 0,458 & 0,736 & 0,472 & 0,751 \\
\hline $\mathrm{Na}$ & 10 & 14 & 9 & 8 & 8 & 6 & 7 & 7 & 11 & 13 & 9 & 8 & 14 & 8 & 17 \\
\hline $\mathbf{N}$ & 259 & 259 & 259 & 259 & 259 & 259 & 259 & 259 & 259 & 259 & 259 & 259 & 259 & 259 & 259 \\
\hline
\end{tabular}

Fonte: Arlequin 3.5 
Tabela 5 - Resultados do teste exato para o cálculo do equilíbrio de HardyWeinberg. Valores de $p>0,05$ apresentam-se não significantes e <0,05 significantes.

\begin{tabular}{|c|c|c|c|c|c|c|}
\hline LOCUS & \#GENOT & OBS. HET & EXP. HET & P - VALUE & S.D & STEPS DONE \\
\hline D8S1179 & 259 & 0.81467 & 0.80127 & 0.06514 & 0.00020 & 1001000 \\
\hline D21S11 & 259 & 0.80695 & 0.83530 & 0.24317 & 0.00037 & 1001000 \\
\hline D7S820 & 259 & 0.80695 & 0.79595 & 0.23947 & 0.00042 & 1001000 \\
\hline CSF1PO & 259 & 0.74903 & 0.72930 & 0.01324 & 0.00009 & 1001000 \\
\hline D3S1358 & 259 & 0.81081 & 0.76751 & 0.33128 & 0.00041 & 1001000 \\
\hline TH01 & 259 & 0.75676 & 0.77933 & 0.18432 & 0.00045 & 1001000 \\
\hline D13S317 & 259 & 0.80695 & 0.82233 & 0.28175 & 0.00040 & 1001000 \\
\hline D16S539 & 259 & 0.72973 & 0.79293 & 0.09535 & 0.00028 & 1001000 \\
\hline D2S1338 & 259 & 0.85714 & 0.87218 & 0.63583 & 0.00038 & 1001000 \\
\hline D19S433 & 259 & 0.78378 & 0.81351 & 0.74148 & 0.00031 & 1001000 \\
\hline vWA & 259 & 0.74903 & 0.76853 & 0.25631 & 0.00036 & 1001000 \\
\hline TPOX & 259 & 0.71815 & 0.69506 & 0.93613 & 0.00023 & 1001000 \\
\hline D18S51 & 259 & 0.89189 & 0.86967 & 0.62138 & 0.00025 & 1001000 \\
\hline D5S818 & 259 & 0.73359 & 0.70176 & 0.48153 & 0.00033 & 1001000 \\
\hline FGA & 259 & 0.89575 & 0.87909 & 0.02314 & 0.00010 & 1001000 \\
\hline
\end{tabular}

Os loci que apresentaram maior probabilidade de exclusão foram os FGA, D2S1338 e D18S51 com valores de 0,75; 0,74 e 0,73 respetivamente. Todos os loci analisados apresentaram resultados do PE que variam de 46-75\%. A Figura 23 representa a probabilidade de exclusão (PE) de amostras para os 15 marcadores STR utilizados na população do Paraguai, realizada com 0 software GenAIEx 6.5

Figura 23 - Probabilidade de exclusão para os 15 loci analisados.

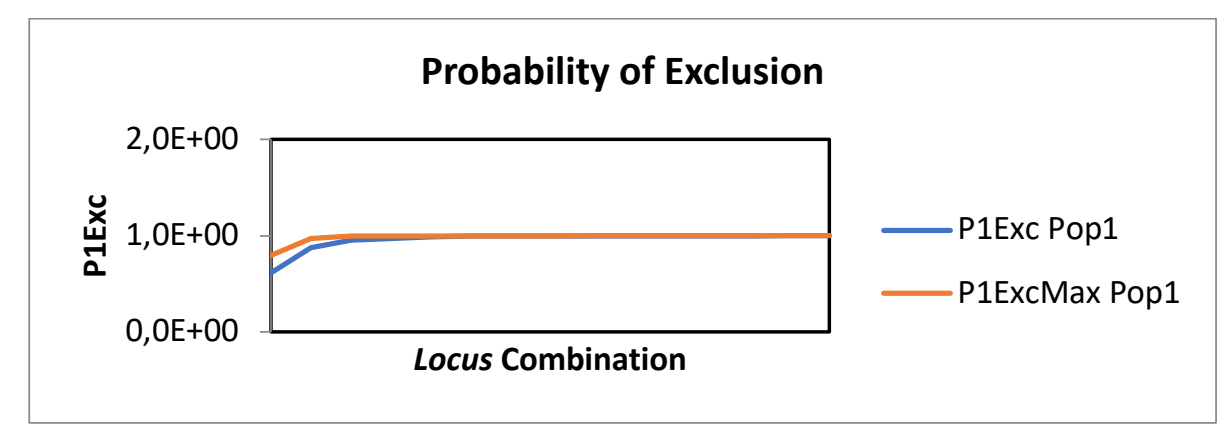

Fonte: Software GenAIEx 6.5 
Os resultados do poder de discriminação (PD) apresentaram valores altos para todos os loci estudados, sendo que os que mostraram maior PD foram D2S1338, FGA e D18S51, todos com 0,96. Porém, os loci de menor PD foram TPOX e TH01 com 0,85.

Os valores da Probabilidade de Coincidência, Probabilidade de identidade ou Probabilidade de Matching (MP), ou seja, a probabilidade de que duas pessoas não relacionadas compartilharem um mesmo perfil genético na população estudada variaram de 0,032 (D2S1338) a 0,148 (TPOX).

Continuando com os parâmetros forenses, os loci com maior Conteúdo Informativo de Polimorfismo (PIC) foram FGA, D2S1338 e D18D51 com valores de 0,861; 0,85 e 0,85 respectivamente. Já o locus TH01 apresentou o menor PIC com 0,647 sendo ainda muito informativo.

A população paraguaia apresentou uma diversidade genética intrapopulacional de $0.794915+/-0.398369$ e interpopulacional determinada pelo índice de fixação (FST) de 0,011 com valor de $p=0,000$. A Tabela 6 expõe os resultados do teste de variância molecular (AMOVA) entre as populações. Não há variância entre grupos populacionais, ou seja, entre populações americanas e a população paraguaia $(0 \% ; p=0,79772)$. Há variância muito pequena, porém significativa entre populações Americanas (1,67\%; $p=0,00000)$. A maior parte da variância se encontra dentro das populações e é significativamente alta $(98,89 \% ; p=1,00000)$. Estes resultados estão expostos nas Tabelas 6-7 e nas Figuras 8-22.

Tabela 6 - Resultados globais do teste AMOVA

\begin{tabular}{lcccc}
\hline $\begin{array}{l}\text { SOURCE OF } \\
\text { VARIATION }\end{array}$ & D.F & $\begin{array}{c}\text { SUM OF } \\
\text { SQUARES }\end{array}$ & $\begin{array}{c}\text { VARIANCE } \\
\text { COMPONENTS }\end{array}$ & $\begin{array}{c}\text { PERCENTAGE } \\
\text { OF VARIATION }\end{array}$ \\
\hline Among groups & 1 & 31.873 & $-0.03388 \mathrm{Va}$ & -0.56212 \\
$\begin{array}{l}\text { Amog } \\
\text { populations } \\
\text { within groups }\end{array}$ & 3 & 166.114 & $0.10091 \mathrm{Vb}$ & 1.67414 \\
$\begin{array}{l}\text { Within } \\
\text { populations }\end{array}$ & 2585 & 15404.565 & $5.95921 \mathrm{Vc}$ & 98.66741 \\
TOTAL & 2589 & 15602.553 & 6.02625 & \\
\hline
\end{tabular}


Figura 24 - Porcentagem de variância molecular.

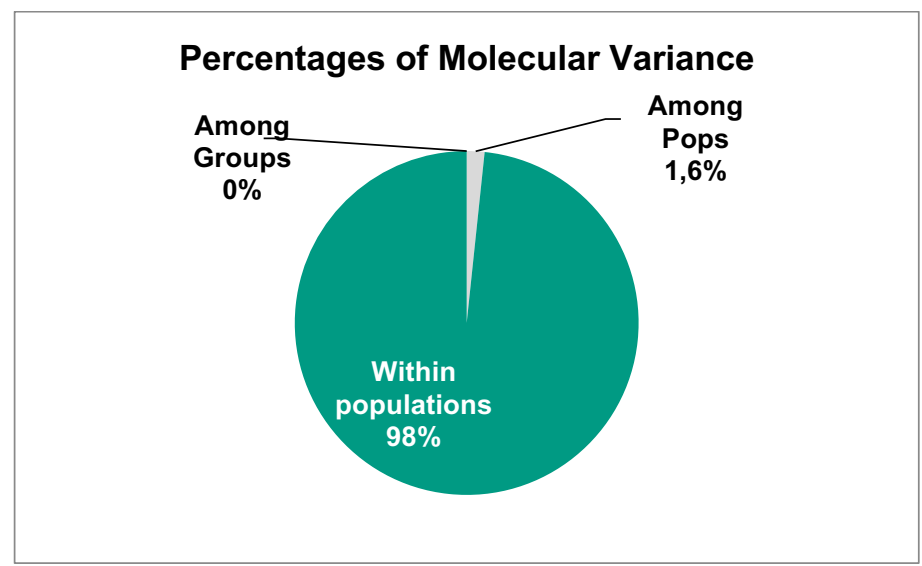

Fonte: Software GenAIEx 6.5

Figura 25 - Valores de FST para as populações comparadas.

\begin{tabular}{|lccccc|}
\hline \multicolumn{5}{c|}{ Pairwise Population Fst Values } & \\
Afro-americanos & 0,00000 & & & & \\
Caucasianos & 0,01943 & 0,00000 & & & \\
Hispanos & 0,01509 & 0,00510 & 0,00000 & & \\
Asiáticos & 0,02959 & 0,02534 & 0,01705 & 0,00000 & \\
Paraguay & 0,01870 & 0,00708 & 0,00178 & 0,02139 & 0,00000 \\
\hline
\end{tabular}

Fonte: Software Arlequin

Figura 26 - Gráfico da matriz de FST para as populações comparadas.

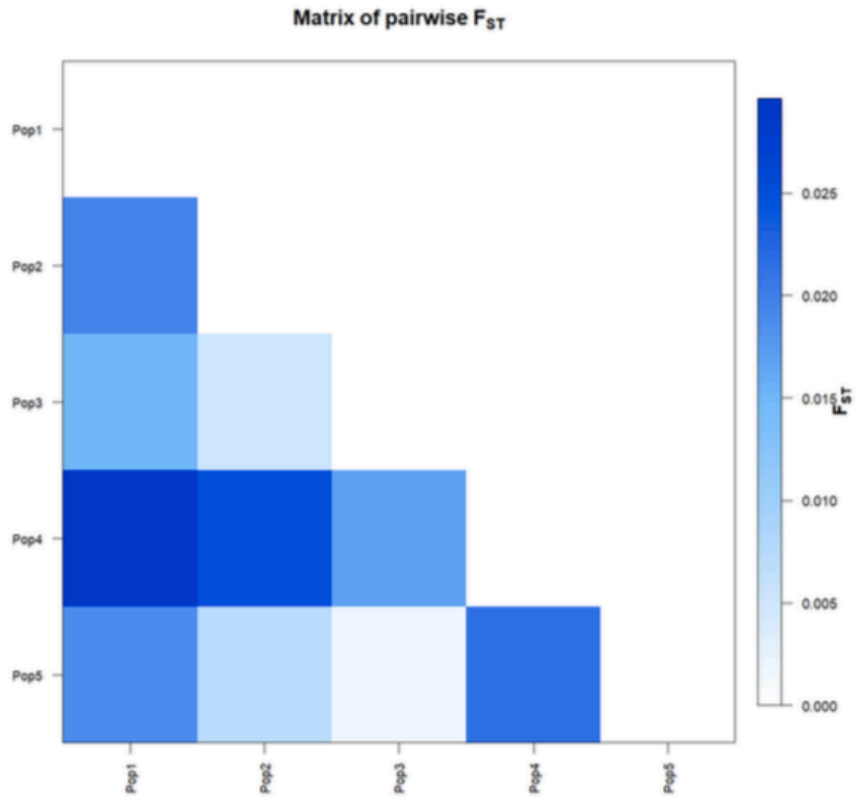

Fonte: Software Arlequin 
Tabela 7 - Resultados da estatística F

\begin{tabular}{ccc}
\hline F-Statistics & Value & $\mathrm{P}($ rand $>=$ data $)$ \\
\hline Frt & $-0,010$ & 1,000 \\
Fsr & 0,017 & 0,001 \\
Fst & 0,011 & 0,000 \\
Fis & 0,002 & 0,273 \\
Fit & 0,009 & 0,001 \\
\hline
\end{tabular}

Fonte: Software GenAIEx 6.5

\section{DISCUSSÃO}

O trabalho apresenta a distribuição das frequências alélicas dos 259 indivíduos paraguaios para os loci autossômicos analisados, bem como os parâmetros forenses. Os loci mais polimórficos na população paraguaia foram FGA e D18S51. A maioria das frequências genotípicas estão distribuídas de acordo com o esperado, portanto encontram-se em equilíbrio de HardyWeinberg. A população paraguaia apresentou maior discrepância com a população Asiática e menor com a Hispana.

Vivenciamos um mundo marcado por várias formas de violência. Atualmente, no tocante a criminalidade, pesquisas demonstraram que um dos fatores que pode potencializar a criminalidade é o tamanho da população residente. (GUIRARDI; MANOLESCU, 2009). Colocando isto no contexto da realidade da população estudada neste trabalho, podemos observar que o Paraguai possui aproximadamente sete milhões de habitantes, portanto é possível antever uma certa facilidade no controle da criminalidade do país.

De fato, a criminalidade no Paraguai, em 2002 enfrentou a sua mais alta taxa de homicídios: 24,63 homicídios por 100 mil habitantes. Entre o ano 2010 e 2015 a taxa de criminalidade do país aumentou $19,3 \%$ segundo o estudo denominado "Crime, Prisão e Insegurança", apresentado pelo Instituto de Estudos Comparados em Ciências Criminais e Sociais do Paraguai - INECIP (LESCANO, 2017).

Entretanto, no contexto internacional, em 2017, a taxa de homicídios no citado país, representou uma das menores nos últimos 10 anos (UNODC, 2013). 
Atualmente, segundo a organização internacional In Sight Crime, o Paraguai é um dos menos violentos da América Latina. Tem a terceira menor taxa de homicídios da América do Sul $(7,98)$, perdendo apenas para o Chile $(2,97)$ e 0 Uruguai $(7,81)$ (RIBEIRO; BORGES; CANO,2015).

Mesmo com uma taxa de criminalidade baixa, a maioria de casos sem resolução no Paraguai são justamente por falta de recursos ou técnicas científicas que permitam demonstrar a implicância de um suspeito no fato a ser provado. Os casos então são baseados em testemunhas e não em evidencias concretas (OEA, 2010). Isso reflete a necessidade de estabelecer métodos científicos válidos e reconhecidos internacionalmente, que permitam provar por meio de fundamentos teóricos aqueles fatos, e facilitar assim o trabalho das autoridades judiciais.

As técnicas atuais de biologia molecular têm revolucionado amplamente as investigações criminais. Inúmeros avanços foram feitos tanto em velocidade quanto na sensibilidade de processamento de amostras nos últimos anos. Testes que anteriormente levavam 6 ou 8 semanas agora podem ser realizados em poucas horas (PHILLIPS ML, 2008). Além disso, as novas técnicas não exigem grandes manchas de sangue com o DNA bem preservado. Pequenas quantidades de amostra (0,5 a 2,0 ng de DNA) e inclusive degradadas, podem ser recuperadas e estabelecer o perfil genético útil em casos forenses. (BUTLER, 2010; OLIVEIRA, 2012)

Esta alta sensibilidade além de ser uma vantagem, às vezes pode dificultar a realização das pesquisas, principalmente quando se trata de pesquisadores com pouca experiência na área ou por falta de instrumentais adaptados às necessidades das técnicas modernas. No nosso trabalho, foram utilizados os cartões de coleta NUCLEIC-CARD ${ }^{\mathrm{TM}}$ Collection Device. (Thermo Fisher Scientific $^{T M}$, São Paulo, Brasil.) Para o processamento do DNA presente nestes cartões é recomendável a utilização de picotes (ou cortes) de $1.2 \mathrm{~mm}$, entretanto no mercado apenas estavam disponíveis de $2 \mathrm{~mm}$.

Nas primeiras corridas foram utilizados picotes de $2 \mathrm{~mm}$, porém os resultados não foram satisfatórios. Segundo BUTLER (2010), o excesso de DNA resulta em eletroferogramas exagerados, de difícil interpretação, ou simplesmente sem leitura, o que aconteceu no nosso trabalho inicial. Paralelamente, muito pouco DNA pode resultar em perda de alelos devido à amplificação estocástica e falha 
em igualar os alelos STR presentes na amostra (CRUZ et al., 2015). Em corridas posteriores, esse erro foi corrigido conseguindo assim eletroferogramas ótimos.

Para a utilização de perfis genéticos nas investigações criminais, é importante conhecer alguns parâmetros genéticos de interesse forense, bem como a caracterização genética da população em questão (FERREIRA, 2011; CASTRO, 2013). Assim, a genética de populações cumpre um papel muito importante, já que é o estudo da variação herdada e sua modulação no tempo e no espaço. A quantificação da variação populacional é importante porque a variabilidade é uma condição para que exista evolução (OLIVEIRA, 2012).

Evolução é tradicionalmente definida como "alteração nas frequências gênicas" não há como evoluir se não houver tal variação (YOKOTO, 2009). A variação, ou variabilidade, permite que a população se adapte, por exemplo, a modificações ambientais. Portanto, o estudo da genética de populações é uma tentativa de quantificar a variação observada dentro de um grupo populacional ou entre diferentes grupos populacionais em termos de frequências alélicas e genotípicas (HEDRICK, 2005, HARTL; CLARK, 2007; BUTLER, 2010).

Amostras populacionais bem caracterizadas com descrições antropológicas seriam desejáveis em muitos casos para definir cuidadosamente grupos populacionais, mas não são necessários para obter informações válidas em bancos de dados populacionais de DNA forenses (BUTLER,2010). Também é desejável a utilização de indivíduos não relacionados nos estudos genéticopopulacionais, a fim de melhorar a precisão das estimativas de frequência alélica, aumentando o número de alelos independentes amostrados (BUTLER,2010).

Como a distribuição da frequência alélica de qualquer marcador de DNA é variável entre populações distintas, se fazem necessários estudos de frequências locais para conhecer os alelos mais comuns em uma determinada região, a fim de definir os marcadores mais informativos para as investigações forenses. Os polimorfismos genéticos se estabeleceram e se disseminaram por meio da migração e miscigenação de populações, podendo apresentar variações étnicas e regionais. (FREDERICO, 2015)

Este estudo é pioneiro na análise da estrutura populacional de amostras de indivíduos nascidos no Paraguai. Como não há relatos sobre outra pesquisa no país, os resultados das frequências alélicas dos STR nessa população foram 
comparados com estudos publicados anteriormente em outras populações dos Estados Unidos (BUTLER; HILL; COBLE, 2012; COBLE; HILL; BUTLER, 2013; HILL et al., 2013) incluindo subgrupos Asiáticos, Afro americanos, Hispanos e Caucasianos.

A análise das frequências alélicas e genotípicas permite inferir o grau de polimorfismo dos microssatélites para caracterizar a variabilidade genética da população (DI LONARDO et al., 2004). Neste sentido, os nossos resultados podem permitir, no futuro, a criação de um banco de dados populacional, fundamental para a comparação genética em casos forenses ou investigações criminais do país.

$\mathrm{Na}$ amostra populacional analisada foi possível verificar que a maioria das frequências genotípicas estão distribuídas de acordo com o esperado em equilíbrio de Hardy-Weinberg, com exceção dos loci FGA e CSF1PO que apresentaram valores de $P=0,01$, inferiores ao nível de significância admitido de 0,05, diferente de outros estudos feitos no Brasil onde o marcador D21S11 se mostrou em desequilíbrio (OLIVEIRA, 2012).

Desvios do equilíbrio de Hardy-Weinberg (HWE) podem indicar endogamia, estratificação populacional e até mesmo problemas na genotipagem. Em amostras de indivíduos afetados, esses desvios também podem fornecer evidências de associação (WIGGINTON; CUTLER; ABECASIS, 2005).

Entretanto, com estes achados, ainda não seria correto falar que a população do Paraguai se-encontra em desequilíbrio, já que essa situação afetaria vários marcadores. A seleção natural, alelos nulos, o acaso, etc., são causas comuns desta situação (DAKING; AVISE, 2004). Quando um marcador não se encontra em equilíbrio é importante observar a diferença entre a Heterozigosidade observada e esperada (BUTLER, 2010).

No caso em tela, o marcador FGA apresentou uma $\mathrm{H}_{\mathrm{o}}$ de 0,89 e uma $\mathrm{H}_{\mathrm{e}}$ de 0,87 e o marcador CSF1PO uma $\mathrm{H}_{\mathrm{o}}$ de 0,74 e uma $\mathrm{H}_{\mathrm{e}}$ de 0,72 não existindo assim uma diferença significativa e observando inclusive mais heterozigotos do esperado. Esta situação permite excluir a hipótese de que o desequilíbrio seja por causa de alelos nulos (alelos que não amplificam), pois, nesse caso, observaríamos menos heterozigotos do esperado, sendo possível, portanto atribuir esse desequilíbrio apenas ao acaso (DAKIN; AVISE, 2004). 
Os loci que se apresentaram mais polimórficos foram FGA, D18S51, D19S433, D21S11, D2S1338. Resultados similares foram obtidos em outros estudos como GRATTAPAGLIA et al., 2001; AGUIAR et al., 2011 e SANTA RITA, 2012.

Paralelamente, os loci que se apresentaram como menos polimórficos em nosso estudo foram o TH01, D13S317 e D16S539. O polimorfismo baixo encontrado no locus D13S317 na população do Paraguai, é similar ao apresentado por GRATTAPAGLIA et al., 2001 e CASTRO, 2013 em populações brasileiras.

As frequências alélicas de cada marcador, estão expostas na Tabela 4. Nesse momento serão discutidas apenas as frequências de três marcadores que se apresentaram mais polimórficos no nosso estudo.

O marcador FGA é um STR localizado no braço longo do cromossomo 4 (NIST, 2014). Na população estudada, neste marcador foram observados 17 microvariantes alélicas. Os alelos 24, 21 e 23 apresentaram uma maior frequência, concordando com resultados expostos por FIGUEIREDO, 2009; FRANCEZ et al., 2011 e MANTA et al., 2012. Entretanto, diferente de outros estudos onde o alelo 22 mostrou-se mais frequente em este marcador. (FRIDMAN et al., 2008; BRISIGHELLI et al., 2009; GAIBAR et al., 2010 e KEE et al., 2011; SILVA et al., 2011; ARANHA, 2012; VIERA et al., 2013).

O locus D18S51, localizado no braço longo do cromossomo 18 (NIST, 2014), foi o segundo marcador mais polimórfico na população paraguaia, apresentando 14 microvariantes alélicas. O alelo 14 foi o de maior frequência seguido pelos alelos 15 e 12 concordando com estudos em outras populações como México (LUNA-VAZQUEZ et al., 2005), Itália (BRISIGHELLI et al., 2009), Portugal (LOPES et al., 2009), China (DENG et al., 2011), e no Brasil; Mato Grosso do Sul (FIGUEIREDO, 2009) e Paraíba (CASTRO, 2013).

O marcador D19S433 é um STR localizado no braço longo do cromossomo 19 (NIST, 2014). No nosso estudo, foram observadas 13 microvariantes alélicas neste marcador, sendo o alelo 14 o mais frequente; seguido pelos alelos $13 \mathrm{e}$ 15. O alelo 14 também foi o mais frequente em outras populações estudadas; Brasileira; especificamente Paraíba (CASTRO, 2013), Mato Grosso do Sul, (FIGUEIREDO, 2009), e São Paulo (FRIDMAN et al., 2008), população Mexicana (LUNA-VAZQUEZ, 2005), Espanhola (CAMACHO et al., 2007), e 
Portuguesa (LOPES et al., 2009). Já nos estudos feitos na China (DENG et al, 2011) e no Brasil, especificamente no Rio de Janeiro (ARANHA, 2012) o alelo 13 foi o mais frequente.

Analisando os parâmetros mostrados na Tabela 4 por meio dos testes estatísticos, observou-se que para todos os marcadores, os índices de Heterozigosidade esperados situam-se próximos aos níveis de Heterozigosidade observados. O locus FGA apresentou o maior nível de Heterozigosidade $H_{\circ}(89,5 \%)$, seguido pelos loci D18S51 $(89,1 \%)$ e D2S1338 $(85,7 \%)$ enquanto que o locus TPOX apresentou o menor nível $(71,8 \%)$, sendo este, portanto, o de menor grau de variabilidade, corroborando com os estudos de GRATTAPAGLIA et al. em 2001.

A probabilidade de exclusão, reflete a probabilidade de excluir a paternidade de um suposto pai da população em relação a um par mãe-filho (BEIGUELMAN, 2008). No nosso trabalho os loci que apresentaram maior probabilidade de exclusão foram os FGA, D2S1338 e D18S51. Todos os loci analisados apresentaram resultados de PE superiores a 45\%, variando de $46-75 \%$.

$\mathrm{Na}$ pratica pericial, os testes de vinculo biológico, objetivam estabelecer ou não uma relação de parentesco, podendo assim ter consequências jurídicas. A busca pela verdade em um processo judicial impede que a filiação seja baseada apenas em suposições ou presunções (SILVA CAL, 2011). O exame de DNA é um meio capaz de conferir a filiação com certeza praticamente absoluta (99,99\%). Portanto, a prova genética obtida pelo teste baseado em marcadores de DNA é atualmente uma das mais escolhidas, pelo grau de eficácia e confiabilidade (SILVA, 2008).

Os valores de Probabilidade de coincidência, ou matching (MP), ou seja, a probabilidade de duas pessoas não relacionadas compartilharem um mesmo perfil genético na população estudada variaram de 0,032 a 0,148. O D2S1338 foi o locus com menor MP, e o TPOX o de maior, concordando com os resultados de CASTRO (2013) e OLIVEIRA (2012).

Os resultados do poder de discriminação (PD) apresentaram valores altos para todos os loci estudados, sendo que os que mostraram maior PD foram D2S1338, FGA e D18S51, todos com 0,96. Porém, os loci de menos PD foram TPOX e TH01 com 0,85. 
O conteúdo de polimorfismo informativo (PIC) é uma medida do grau de polimorfismo de um locus e é dependente do numero e da frequência dos alelos. A população paraguaia apresentou valores altos; dentre $64-76 \%$ sendo os loci FGA $(0,861)$ e TH01 $(0,647)$ os de maior e menor valor de PIC respetivamente. Todos os loci analisados podem ser considerados bastante informativos, ou seja, úteis na identificação humana, devido a apresentaram valores superiores a 0,5 (BOTSTEIN et al., 1998 apud MORETI, 2011).

A população paraguaia apresentou uma diversidade genética intrapopulacional de $0.794915+/-0.398307$ ou seja, espera-se que o $79 \%$ da população seja heterozigota. Todos os alelos encontrados na população do Paraguai estão descritos na base de dados de STR do NIST (National Institute Of Standards And Technology), portanto a população estudada não apresentou alelos raros.

A diversidade interpopulacional determinada pelo índice de fixação (FST) apresentou um valor de 0,01112 ( $p=0,000)$ mostrando assim que não existe diferenciação entre as populações. Quando o valor de FST é superior a 0,25 considera-se que as populações são altamente diferenciadas, e valores menores a 0,1 apresentam baixa diferenciação (HEDRICK, 2006). Observando a matriz de FST (Figura 25) é possível observar que a população do Paraguai possui maior diferenciação com a Asiática, seguida da Afro americana, e menor similitude com a Caucasiana e a Hispana.

A comparação das frequências alélicas dos STR estudados bem como os parâmetros forenses observados na população do Paraguai de forma geral apresentam ampla distribuição em diversas populações internacionais. Desde o ponto de vista forense estes achados são importantes devido a que os kits de identificação humana disponíveis atualmente no mercado e validados em populações similares seriam, portanto uteis e efetivos também na população paraguaia, uma questão discutida quando são utilizados exames de DNA em populações que não possuem estudos genético-populacionais (BUTLER, 2010; PINHEIRO, 2010; PINHEIRO, 2015).

Por fim recomenda-se a realização de mais estudos populacionais em outras regiões da população do Paraguai, mesmo que o tamanho amostral proposto na nossa pesquisa segundo dados estatísticos mostra-se significante; a fim de 
traduzir melhor a realidade da composição genética e posteriormente pensar na criação de um baco de dados genético populacional.

\section{CONCLUSÕES}

A partir desse estudo, foi possível determinar as frequências alélicas de 15 STRs utilizados no sistema CODIS na capital e no Departamento Central do Paraguai bem como a caracterização genética da população estudada.

A população avaliada neste trabalho, encontra-se em equilíbrio de HardyWeinberg para todos os loci exceto FGA e CSF1PO.

Todos os loci estudados na população paraguaia foram considerados muito informativos. Os parâmetros forenses calculados mostraram que os loci estudados são uteis para a solução de problemas relacionados com identificação humana na amostra analisada.

Estes dados corroboram e confirmam a possibilidade da criação de um banco de dados genético-populacional no Paraguai utilizando os marcadores preconizados no CODIS.

\section{REFERENCIAS}

ABOVICH et al. Allele frequencies of 15 STRs loci in an Argentine population sample. Forensic Science International: Genetics Supplement, v. 2, p. 369370, 2009.

AGUIAR, V. R. C. et al. New CODIS core loci allele frequencies for 96,400 Brazilian individuals. Forensic Science International: Genetics, v. 13, p. e6e12, 2014.

ALVAREZ-CUBERO, M.J. et al. Nuevas aplicaciones en identificación genética. Cuad. med. forense, Málaga, v.16, n.1-2, p.5-18, 2010 . Disponible en

$<$ http://scielo.isciii.es/scielo.php?script=sci_arttext\&pid=S1135$76062010000100002 \&$ Ing $=$ es\&nrm=iso $>$.

ARANHA, T.H.C. Frequências alélicas, parâmetros estatísticos de natureza forense e caracterização étnica da população do Rio de Janeiro, através de polimorfismos do tipo STR. 2012. 91f. Tese (Mestrado em Biologia Celular e Molecular) - Instituto Oswaldo Cruz, Pós-Graduação em Biologia Celular e Molecular. Rio de Janeiro, 2012.

BECERRA V, PAREDES C. Uso de marcadores bioquímicos y moleculares en estudios de diversidad genética. Agricultura Técnica, Santiago, v. 60, n.3, p. 270-281, 2000. 
BEIGUELMAN B. Genética de Populações humanas. Editora SBG Sociedade Brasileira de Genética. Ribeirão Preto, SP. p.61-73, 2008.

BERNATH, V. EI ADN como herramienta para la resolución de procesos judiciales. Pasado, presente y futuro. Química Viva, Buenos Aires, v. 7, n.2, p.103-112, 2008.

BOTSTEIN D, et al. Construction of a genetic linkage map in man using restriction fragment length polymorphisms. American Journal of Human Genetics, v. 32, p. 314- 331, 1980.

BUDOWLE B, BIEBER F, EISENBERG A. Forensic aspects of mass disasters: strategic considerations for DNA-based human identification. Legal Medicine. v.7, n.4, p.230-243, 2005.

BUTLER J. Advanced Topics in Forensic DNA Typing: Methodology. San Diego: Academis Press, 2010.

BUTLER J. Fundamentals of Forensic DNA Typing. San Diego: Academis Press, 2010.

BUTLER JM, COBLE MD, VALLONE PM. STRs vs. SNPs: thoughts on the future of forensic DNA testing. Forensic Science, Medicine and Pathology. v.3, n.3. p200-205, 2017

BUTLER, J.M, HILL, C.R, COBLE, M.D. Variability of new STR loci and kits in U.S. population groups. Profiles in DNA, 2012. Available at http://www.promega.com/resources/articles/profiles-in-dna/2012/variability-ofnew-str-loci-and-kits-in-us-population-groups/.

BOTSTEIN, D., et al. Construction of a genetic linkage map in man using restriction fragment length polymorphisms. American Journal of Human Genetic. v. 32, p.314-331, 1980.

BRISIGHELLI, F, et al. Allele frequencies of fifteen STRs in a representative sample of the Italian population. Forensic Science International: Genetics, v.3, n.2, p.e29-e30, 2009.

CARVALHO, SPM, et al . Quality evaluation of DNA obtained from stored human saliva and its applicability to identification in Forensic Dentistry. Rev. odonto ciênc. (Online), Porto Alegre, v. 25, n. 1, p. 48-53, 2010 . Available from $<$ http://www.scielo.br/scielo.php?script=sci_arttext\&pid=S1980-

65232010000100010\&lng=en\&nrm=iso>. access on 13 Sept. 2018. http://dx.doi.org/10.1590/S1980-65232010000100010.

CASTRO S.G. Estudo de frequências alélicas de 15 strs autossômicos na população paraibana. 2012. 90f. Tese (Mestrado em Biologia Celular e Molecular) - Centro de Ciências Exatas e da Natureza, Universidade Federal da Paraíba, João Pessoa 2013. 
CAMARGO, C. Dignidade humana e a ciência: a proteção da vida em conflito. Em tempo, v.12, p.83-100, 2013

CAVALCANTE T, QUEIROZ P. Banco de dados baseado em marcadores genéticos. Mostra de produção cientifica da pós-graduação lato sensu. Goiás: Pontifícia Universidade Católica de Goiás, p.840-859, 2013

COBLE, M.D., HILL, C.R., BUTLER J.M. Haplotype data for 23 Y-chromosome markers in four U.S. population groups. Forensic Science International: Genetics. v.7, e66-e68, 2013

COMISSÃO NACIONAL DE ÉTICA EM PESQUISA. Manual operacional para comitês de ética em pesquisa. Robson Alves Santos Editora. Brasilia, 2002.

COLLINS P, et. al. Developmental validation of a single-tube amplification of the 13 CODIS STR loci, D2S1338, D19S433, and amelogenin: the AmpFISTR Identifiler PCR Amplification Kit. Journal of Forensic Science, v.49, n.6, p.12651277, 2004.

DAKIN E.E, AVISE J.C. Microsatellite null alleles in parentage analysis. Heredity, v. 93, p. 504-509, 2004.

DENG Y.J, et al. Genetic polymorphism analysis of 15 STR loci in Chinese Hui ethnic group residing in Qinghai province of China. Molecular Biology Reports, v. 38, n.4, p.2315-2322, 2011.

DESMARAIS, D, et al. Development of a highly polymorphic STR marker for identity testing purposes at the human androgen receptor gene (HUMARA). Journal of Forensic Science. v. 43, p. 1046-1049, 1998.

DIAS R, et al. Polimorfismos genéticos determinantes da performance física em atletas de elite. Revista Brasileira de Medicina do Esporte, v.13, n.3, 2007.

DIXON, L. A. et al. Analysis of artificially degraded DNA using STRs and SNPs: results os a colaborative European exercise. Forensic Science International. v. 164, p. 33-44, 2006.

DUARTE MO. La prueba de AND. Abc Color, 2006. Disponível em: http://www.abc.com.py/edicion-impresa/suplementos/salud/la-prueba-de-adn936893.html Acesso em: 14 agosto de 2018.

EHRLICH P, RAVEN P. Differentiation of Populations. American Association for the Advancement of Science. v. 165, n.3899, p1228-1232, 1969.

EXCOFFIER L, LISCHER H.E.L. Arlequin suite ver 3.5: A new series of programs to perform population genetics analyses under Linux and Windows. Molecular Ecology Resources. v. 10, p. 564-567, 2010.

FEDERAL BUREAU OF INVESTIGATION. CODIS System, USA. Disponível em: <www.fbi.gov> Acesso em: 25 abr. 2018. 
FIGUEIREDO, $H$. Avaliação das frequências alélicas de 15 marcadores STRs na população de pessoas nascidas no estado de Mato Grosso do Sul. 2009. 53f. Tese (Mestrado em Biotecnologia) - Universidade Católica João Bosco. Campo Grande/PB, 2009.

FORENSIC GENETICS POLICY INITIAVIVE. Setting Human Rigths standars DNA Database Worldwide. Disponivel em http://dnapolicyinitiative.org/ Acesso em: 25 abr. 2018.

FRANCEZ P.V.A, et al. Alelic frequencies and statistical data obtained form 12 codis STR in an admixed population of the Brazilian Amazon. Genetic Molecular Biology, v.34, n.1, p.35-39, 2011.

FREDERICO P. Análise de frequências alélicas de 15 marcadores STR em alunos da Faculdade de Odontologia de Bauru. 2015. 107f. Tese (Doutorado em ciencias odontológicas aplicadas) - Faculdade de Odontologia de Bauru, Universidade de São Paulo. Baurú, 2015

FERREIRA, L.V. Estimativa das frequências alélicas d os 15 marcadores autossômicos STR CODIS da população goianiense do Brasil Central. 2011. 86f. Tese (Mestrado em Genética) - Universidade Católica de Goiás. Goiânia, 2011

FRIDMAN C, et al. Brazilian population profile of 15 STR markers. Forensic Science Internacional: Genetics, v.2, p. e1-e4, 2008.

GAIBAR M, et al. STR genetic diversity in a Mediterranean population from the south of the Iberian Peninsula. Annals of Human Biology, v.37, n.2, p.253-266, 2010.

GUIRARDI, E R., MANOLESCU, F M K. Criminalidade E Violência No Brasil. XIII Encontro Latino Americano de Iniciação Científica e IX Encontro Latino Americano de Pós-Graduação, 2009

GRATTAPAGLIA D, et al. Brazilian population database for the 13 STR loci of the AmpFISTR Profiler Plus and Cofiler multiplex kits. Forensic Science International, v. 118, p. 91-94, 2001.

GIGONZAC T. Caracterização Genética da População do Estado de Goiás baseada em Marcadores STRs Autossômicos e do Cromossomo Y. 2013. 71f. Tese (Doutorado em Biologia Celular e Molecular). Universidade Federal de Goiás, Goiânia, 2013.

GOBIERNO NACIONAL. Dirección General de Estadística, Encuestas y Censos. Demografía. Gobierno Nacional. Disponivel em http://www.dgeec.gov.py/Publicaciones/Biblioteca/Juventud/JU004.htm Acesso em: 10 mai. 2018.

GOBIERNO NACIONAL. Dirección General de Estadística, Encuestas y Censos. Proyección de la Población por Sexo y Edad, según Departamento, 2000-2025. 
Gobierno Nacional, 2012. Disponivel em: http://www.dgeec.gov.py Acesso em: 10 mai. 2108.

GOES A. C, et al. Allele frequencies data and statistic parameters for 16 STR loci-D19S433, D2S1338, CSF1PO, D16S539, D7S820, D21S11, D18S51, D13S317, D5S818, FGA, Penta E, TH01, vWA, D8S1179, TPOX, D3S1358-in the Rio de Janeiro population, Brazil. Forensic Science International, v. 140, n. 1, p. 131-2, Feb 102004.

GRIFFITHS A, et al. Introdução à genética. 10. ed. Rio de janeiro: Guanabara Koogan Ltda, 2013.

HARES DR. Addendum to expanding the CODIS core loci in the United States. Forensic Science International: Genetics, v.6, 2012.

HARES DR. Selection and implementation of expanded CODIS core loci in the United States. Forensic Science International: Genetics, v.15, p.33-34, 2015.

HARTL, D.L, CLARK, A.G. Principles of Population Genetics. Ecoscience, v.14, n. 4 , p. 544-545, 2007

HEDRICK, P. Genetic polymorphism in heterogeneous environments: the age of genomics. Annual Review of Ecology, Evolution, and Systematics, v.37, p.67-93, 2006.

HEINRICH, M. et al. Characterisation of variant alleles in the STR systems D2S1338, D3S1358 and D19S433. International Journal of Legal Medicine, v. 119, n. 5, p. 310-3, Sep 2005.

HILL C.R, et al. U.S. population data for 29 autosomal STR loci. Forensic Science. International: Genetics. v.7, p. e82-e83, 2013

HOOD L, GALAS D. The digital code of DNA. Nature. v.421, n.23, p.444-448, 2003.

HOUAISS A, VILLAR MS, FRANCO FM. Dicionário da Língua Portuguesa. Rio de Janeiro, 1ed, p.1264, 2001.

INTERPOL. Disaster Victim Identification Guide, 2014. Disponível em: <www.interpol.int/INTERPOLexpertise/Forensics/DVI-pages/DVI-guide> Acesso em 20 de abril de 2017].

JEFFREYS J, BROOKFIELD J, SEMEONOFF R. Positive identification of an immigration test-case using human DNA fingerprints. Nature, v. 317, p.818-819, 1985.

JOBIM L, COSTA L, SILVA M. Identificação humana. 2 ed. Campinas: Millenium editora Ltda, 2012. 
JOBLING M, GILL P. Encoded evidence: DNA in forensic analysis. Nature Reviews Genetics. v.5, p.739-751, 2004.

KEE B. P, et al. Genetic data for 15 STR loci in a Kadazan-Dunsun population from East Malaysian. Genetic and Molecular Research, v.10, n.2, p.739-743, 2011.

KRAEMER M, et al. Developmental validation of QIAGEN Investigator 24plex QS Kit and Investigator 24plex GO! Kit: Two 6-dye multiplex assays for the extended CODIS core loci. Forensic Science International: Genetics, v.29, p.9-20, 2017

KRISHNAMURTHY, MANOJ, PAGARE. Understanding the Basics of DNA Fingerprinting in Forensic Science. Journal of Indian Academy of Oral Medicine and Radiology, v.23, n4, p.613-616, 2011

LEITE V, et al. Uso das técnicas de biologia molecular na genética forense. Derecho y cambio social, 2013.

LESCANO O. Frías estadísticas: Crimen con tendencia ascendente. $A B C$ Color; edición impresa, 2017

$\mathrm{LI} \mathrm{H}$, et al. A multiplex PCR for $4 \mathrm{X}$ chromossome STR markers and population data form Beijing Ham ethnic group. Legal Medicine, v. 11, p. 248-250, 2009.

LIMA H. DNA x criminalidade. Revista Perícia Federal, Brasília-DF, n.26, p.711, mar. 2008.

LOPES V, et al. Allelic frequency distribution of 17 STRs from identifiler and PowerPlex-16 in Central Portugal area and the Azores archipelago. Forensic Science International: Genetics, v.4, n.1, p.1-7, 2009.

LUNA-VAZQUEZ A, et al. Population data for 15 (Identifiler® Kit) in a sample from the Valley of Mexico. Legal Medicine, v.7, p.331-333, 2005.

MACHADO H, MONIZ H. Bases de Dados Genéticos Forenses. Tecnologias de Controlo e Ordem Social. Coimbra editora, 2014

MANTA F, et al. Indel markers: genetic diversity of 38 polymorphisms in Brazilian populations and application in a paternity investigation with post mortem material. Forensic Science Internacional Genetics, v.6, p.658-661, 2012.

MARTINS J. Estudo de frequências alélicas de STRs do cromossomo $\mathbf{x}$ na população brasileira de Araraquara-Sp. 2008. 122p. Tese (Mestrado Biologia Molecular) - Faculdade de Ciências Farmacêuticas, Universidade Estadual Paulista. Araraquara, 2008.

MARTINS JA, et al. X-chromosome genetic variation in São Paulo State (Brazil) population, Ann Hum Biol, v.37, n.4 p.598-603, 2010. doi:

10.3109/03014460903508512. 
MATOS J, BLANCO M, WEST, S. Cell-Cycle Kinases Coordinate the Resolution of Recombination Intermediates with Chromosome Segregation. Cell Reports. v.4, n.1, p76-78,2018.

MATOS S. Identificação genética humana: Estudo de novos marcadores genéticos do tipo STR e InDel. 2013. 140f. Tese. (Mestrado Biologia Molecular em Saúde) - Escola Superior de Saúde Egas Moniz. Portugal, 2013

MORTON, N. Forces maintaining polymorphisms. Acta Anthropogenetica. v.14, n.3, 1976.

NATIONAL INSTITUTE OF STANDARDS AND TECHNOLOGY (NIST). STRBase, 2014. Disponivel em: https://strbase.nist.gov/NISTpop.htm. Acesso em: 10 jun. 2018

NUFFIELD COUNCIL in Bioethics. The forensic use of bioinformation: ethical issues. Cambridge Publishers Ltd, 2007

PHILLIPS, M. L. Crime Scene Genetics: Transforming Forensic Science through Molecular Technologies. BioScience, v. 58, n. 6, p. 484, 2008.

OLIVEIRA TMM. Análise da frequência alélica de 15 loci str na população do Rio Grande do Norte. 2012. 77P. Tese. (Mestrado em Ciências Farmacêuticas) - Universidade Federal do Rio Grande do Norte. Natal, 2012

ORGANIZACIÓN DE LOS ESTADOS AMERICANOS. Informe Nacional Paraguay. Esttudio de la Seguridad Pública y Privada. Disponivel em < https://www.oas.org/dsp/documentos/publicaciones/informe\%20nacional\%20paraguay.pdf> Acesso em: 10 set 2018.

ORGANIZACIÓN INTERNACIONAL PARA LAS MIGRACIONES. Migración em el Paraguay. Disponivel em <http://paraguay.iom.int/?q=es/node/15> Acesso em: 10 mai 2018.

PEAKALL, R, SMOUSE P.E. GenAIEx 6.5: genetic analysis in Excel. Population genetic software for teaching and research-an update. Bioinformatics v. 28 , p.2537-2539, 2012.

PEAKALL R, SMOUSE P.E. GENALEX 6: genetic analysis in Excel. Population genetic software for teaching and research. Molecular Ecology Notes. v.6, p.288-295, 2006.

PERL-TREVES R, et al. Phylogeny of Cucumis based on isozyme variability and its comparison with the plastome phylogenies. Theoretical and Applied Genetics, v71, n.3, p430-436, 1985.

PHILLIPS, M. L. Crime Scene Genetics: Transforming Forensic Science through Molecular Technologies. BioScience, v. 58, n. 6, p. 484, 2008. 
PINHEIRO, M. Algumas Perspectivas da Identificação Genética. Genética Forense-Perspectivas da identificação genética. Universidade Fernando Pessoa, Porto, p.17-78, 2010.

PINHEIRO, M. Criminalística biológica. In: CORTE-REAL F, VIEIRA D. Princípios de genética forense. Imprensa da Universidade de Coimbra, p.42122, 2015.

R DEVELOPMENT CORE TEAM. R: A Language and Environment for Statistical Computing. R Foundation for Statistical Computing. Austria, 2008. Disponivel em <http://www.R-project.org>

RESENDE, A. Estudo dos marcadores genéticos dos sistemas CODIS e ESS na população imigrante de Cabo Verde residente em Lisboa. 2016. 115p. Tese (Mestrado, Medicina Legal e Ciências Forenses) - Faculdade de Medicina, Universidade de Lisboa, 2016

RIBEIRO E, BORGES D, CANO I. Calidad de los Datos de Homicidio en América Latina. Conferencia sobre calidad de datos de homicidio en américa latina y el caribe". Bogotá, 2015.Disponivel em: http://conferenciahomicidiosbogota2015.org/wpcontent/uploads/2015/08/Calidad-de-los-Datos-de-Homicio-FINALESPA\%C3\%91OL.pdf

ROEWER L. DNA fingerprinting in forensics: past, present, future. Investigative Genetics, v.4, n.1, p.22, 2013.

SANTA RITA TH. Frequências alélicas de 15 strs autossômicos em uma amostra populacional do distrito federal do Brasil. Um território que surgiu do nada. 2013. 97p. Tese (Mestrado em Ciências da Saúde) - Faculdade de Ciências da saúde, Universidade de Brasília, 2013.

SENSABAUGH, G. Biochemical markers of individuality. In: Saferstein R, ed. Forensic Science Handbook. Nova Iorque: Prentice-Hall,338-415,1982.

SILVA B. C, et al. Genetic diversity and statistical parameters of 15 autosomal STRloci in the Pomeranian subpopulation of Espírito Santo State, Brazil. Molecular Biology Reports, v.38,n.5, p.3013-3016, 2011.

SILVA CAL. Importância dos marcadores microssatélites como prova forense de DNA na investigação de vínculo genético. 2011. Dissertação (Especialização em Farmácia e química Forense). Pontifícia Universidade Católica de Goiás. Goiânia, 2011.

SILVA RHA. Estudo de frequência alélica de cinco loci str do cromossomo $x$ na população do estado de são paulo e sua contribuição na identificação humana. 2007, 95p. Tese (Doutorado em Odontologia Social) -Faculdade de Odontologia da Universidade de São Paulo, 2007 
SILVA RGSC, FARINELLI AHP. A tutela jurisdicional do hipossuficiente: a obrigação do estado em custear o exame de DNA nas ações de filiação. Rev. Ciên. e Soc. da Unipar. Umuarama. v. 11, n.2, p. 491-520, 2008.

SNUSTAD D, SIMMONS, M. Fundamentos de Genética. 2 ed. Rio de Janeiro, Guanabara Koogan. p.756, 2001.

SZIBOR R, et al. Use of X-linked markers for forensic purposes. International Journal of Legal Medicine, v.117, n.2, p67-74, 2003.

TURCHETTO-ZOLET A, et al. Marcadores Moleculares na Era Genômica: Metodologias e Aplicações. Ribeirão Preto: Sociedade Brasileira de Genética, $181 p, 2017$.

ULTIMA-HORA. Numerosos homicídios hasta ahora no son esclarecidos. Ultima-Hora, 2007.

UNITED NATIONS OFFICE ON DRUGS AND CRIME (UNODC). 2013 Global Study on Homicide: trends, contexts, data. 2013.

UTIYAMA S, REASON I, KOTZE L. O Sistema Complemento nas Doenças: Genética e Patogenia. The Complement System in Diseases: Genetic and Pathogeny. Revista Brasileira de Reumatologia, v.44, n.4, p. 277-86, 2004

VIEIRA T. C, et al. Allelic frequencies and statistical data obtained from 15 STR in a population of the Goiás State. Genetic and Molecular Research, v.12, n.1, p.23-27, 2013.

WALLACE $\mathrm{H}$, et al. Forensic DNA databases-Ethical and legal standards: A global review. Egyptian Journal of Forensic Sciences, v.4, n.3, p. 57-63, 2017.

WEIR, B. S. Genetic data analysis: methods for discrete population genetic data. 2a ed. Massachusetts: Sinauer Associates 1996.

WIGGINTON E J. CUTLER A J, ABECASIS G R. A Note on Exact Tests of HardyWeinberg Equilibrium. American Journal OF Human Genetics, v.76, n.5, p.887-893, 2005.

WILLIAMS R, JOHNSON P, MARTIN P. Genetic information and crime investigation: social, ethical and public policy aspects of the establishment, expansion and police use of the National DNA Database, Project Report. Durham University, School of Applied Social Sciences, Durham. Wellcome trust, 2004.

YOKOTO K. Genética de Populações. Universidade Federal de Viçosa - UFV Departamento de Biologia Geral, 2009. Disponível em: ftp://ftp.ufv.br/dbg/Bio642/Bio240/Karla/apostilas/GEnetica\%20de\%20Populaco es\%201.pdf 


\title{
9. ANEXO
}

\subsection{ANEXO A - Termo de Consentimento Livre e Esclarecido}

\author{
UNIVERSIDADE DE SÃO PAULO \\ FACULDADE DE MEDICINA DE RIBEIRÃo PRETO
}

\section{CONSENTIMENTO INFORMADO}

ESTUDIO: DISTRIBUCION DE LA FRECUENCIA ALELICA DE STRS PRECONIZADOS POR EL SISTEMA CODIS EN LA CAPITAL Y DEPARTAMENTO CENTRAL DE PARAGUAY.

Usted está siendo invitado (a) a participar del proyecto de investigación arriba citado. Este documento contiene totas las informaciones necesarias sobre la investigación que estamos realizando. Su colaboración en este estudio será muy importante para nosotros, pero si usted desiste en cualquier momento, no le causara ningún prejuicio.

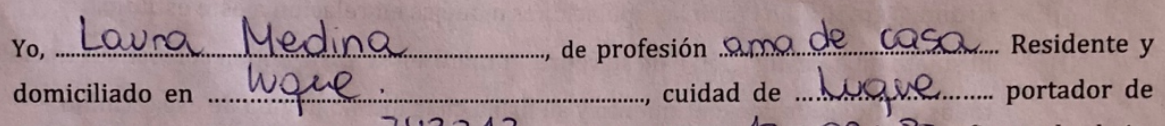
Cédula de identidad número ....................nascido(a) el $17 / 02 / 87$, firmando abajo, acepto de libre y espontánea voluntad en participar como voluntario(a) del estudio "Distribución de la frecuencia alélica de STRs preconizados por el sistema CODIS en la capital y departamento central de Paraguay". Declaro que tuve todas las informaciones necesarias así como todas las eventuales aclaraciones en cuanto a las dudas presentadas por mi. Estoy consciente que:

I) El estudio es necesario para que puedan descubrir la frecuencia de ciertos marcadores genéticos en la población paraguaya, que se utilizan internacionalmente con fines de identificación, lo que permitiría en futuros estudios establecer el perfil genético de la población. Esto sería un importante avance en las ciencias forenses en el país y contribuirá de manera inigualable en el ámbito penal.

II) Será realizada una única colecta de saliva con hisopo, y la muestra se identificará con los siguientes datos: sexo, edad, domicilio.

III) Las muestras serán enviadas a Brasil y se procesarán en el laboratorio de farmacología y genética de la Facultad de Odontología de Bauru, Universidad de Sao Paulo.

IV La participación en este proyecto no apunta a someterme a un tratamiento, y no me causa ningún gasto financiero en relación con los procedimientos llevados a cabo en el estudio;

v) Tengo la libertad para renunciar o dejar la colaboración en este estudio cuando quiera, sin ninguna explicación;

VI) La retirada no causará ningún daño a mi salud o el bienestar físico. 


\section{UNIVERSIDADE DE SÃO PAULO FACULDADE DE MEDICINA DE RIBEIRÃO PRETO}

VII) Los resultados obtenidos durante este estudio serán confidenciales, pero estoy de acuerdo que se publican en revistas científicas, ya que mis datos personales no se mencionan;

VIII) Si quiero, puedo tomar personalmente nota de los resultados al final de esta investigación.

$\aleph$ Deseo conocer los resultados de esta investigación

( ) No deseo conocer los resultados de esta investigación

IX) Estoy de acuerdo en que el material puede ser utilizado en otros proyectos, siempre y cuando autorizado por el Comité de Ética de este Instituto y el responsable de esta investigación. Si mi demostración es positivo, puedo retirar esta autorización en cualquier momento sin ningún daño a mí.

$$
\text { WSi o ( ) No }
$$

$\mathrm{X}$

Podré entrar en contacto con Tamara Frontanilla en el teléfono +595981879095 (e-mail: tfronta@gmail.com) para las apelaciones o quejas en relación a este estudio.

XI) El sujeto de investigación o de su representante, en su caso, deben colocar sus iniciales en todas las hojas de consentimiento y su firma en la última página de ese término

XII) Asimismo, el investigador principal deberá colocar sus iniciales en todas las páginas del Consentimiento Informado y fijar su firma en la última página de ese término.

XIII) Estoy recibiendo una copia de estas Condiciones de Consentimiento.

$$
\text { Asunción, } 20 \text { de Febreno de } 2018
$$

Y. Paciente / ( ) Responsable Q......urea Clesina

Responsable por el Proyecto:



Tamara Frontanilla Recalde.

Especialista en Odontología Legal - Facultad de Odontología de Ribeirão Preto - Universidad de São Paulo (FORP-USP).

Alumna de maestría en la programa de Patología Experimental Facultad de Medicina de Ribeirão Preto - Universidad de São Paulo (FMRP-USP).

Registro profesional numero: 6327 (Paraguay) 


\subsection{ANEXO B - Aprovação do Comité de ética da Faculdade de Ciências Médicas da Universidade Nacional de Assunção.}



